\title{
Dynamic Voltage Restorer (DVR): A Comprehensive Review of Topologies, Power Converters, Control Methods, and Modified Configurations
}

\author{
Ali Moghassemi ${ }^{1}$ (D) and Sanjeevikumar Padmanaban ${ }^{2, *}$ \\ 1 Department of Electrical Engineering, South Tehran Branch, Islamic Azad University, \\ Tehran 1584743311, Iran; moghassemiali@gmail.com \\ 2 Department of Energy Technology, Aalborg University, 6700 Esbjerg, Denmark \\ * Correspondence: san@et.aau.dk; Tel.: +45-71-682-084
}

Received: 21 June 2020; Accepted: 21 July 2020; Published: 11 August 2020

check for updates

\begin{abstract}
Power quality is a pressing concern and of the utmost importance for advanced and high-tech equipment in particular, whose performance relies heavily on the supply's quality. Power quality issues like voltage sags/swells, harmonics, interruptions, etc. are defined as any deviations in current, voltage, or frequency that result in end-use equipment damage or failure. Sensitive loads like medical equipment in hospitals and health clinics, schools, prisons, etc. malfunction for the outages and interruptions, thereby causing substantial economic losses. For enhancing power quality, custom power devices (CPDs) are recommended, among which the Dynamic Voltage Restorer (DVR) is considered as the best and cost-effective solution. DVR is a power electronic-based solution to mitigate and compensate voltage sags. This paper provides a thorough discussion and comprehensive review of DVR topologies based on operations, power converters, control methods, and applications. The review compares the state-of-the-art in works of literature, and comparative study on power quality issues, the DVR principle along with its operation modes, the DVR components, the DVR topologies based on energy storage, the DVR topologies based on single-/three-phase power converters, and the DVR topologies based on control units that have different control processing stages. Furthermore, modified and improved configurations of the DVR, as well as its integration with distributed generations, are described. This work serves as a comprehensive and useful reference for those who have an interest in researching DVRs.
\end{abstract}

Keywords: power quality; dynamic voltage restorer (DVR); power converter; control methods; modified DVR configurations; distributed generation

\section{Introduction}

Over the past few years, the number of sensitive loads such as medical equipment in hospitals and health clinics, schools, prisons, etc. has quadrupled which makes the power quality of the sensitive loads a pressing concern [1]. If the power quality is not high, there could be dire consequences like substantial economic losses, production losses, sensitive and critical loads outage, and missing data [2]. This is why having high power quality is key to the customers, utilities, and also electrical devices producers. Voltage sags, voltage swells, transients, harmonics, fluctuations, flickers, and interruptions are the essential power quality issues [3-6]. They will be all explained further in the following section.

These power quality issues and voltage disturbances must be averted when it comes to sensitive and critical loads. To that end, a wide variety of solutions have been presented among which, power electronics-based devices known as Custom Power Devices (CPDs) are considered as the best and the most cost-effective solution for compensating and mitigating voltage disturbances $[7,8]$. 
CPDs can be connected in parallel, like the Distribution Static Synchronous Compensator (DSTATCOM), in series like the Dynamic Voltage Restorer (DVR), and as parallel-series like the Unified Power Quality Conditioner (UPQC). They serve as compensation systems, and each one has a different control method and application. Their applications/functions will all be explained further in the following section. DSTATCOM is employed to correct the power factor.

UPQC can inject voltage in series and current in parallel at the same time. The size and cost of UPQC and DSTATCOM are more, however, as opposed to DVR [9]. DVR is used as the most cost-effective solution to mitigate voltage sags, as they are the most severe and common power quality issues in the modern power system [10]. Figure 1 shows the DVR schematic in the low voltage network. The DVR as a power electronic-based device injects the desired voltage to the load-side when there is a voltage disturbance at the supply-side. As well as that, the DVR can protect sensitive and critical loads against supply-side disturbances [11,12]. This means that the DVR plays a prominent role in voltage sag compensation and sensitive load protection as well. The DVR is the most effective CPD because its cost is low, its size is small, and it is capable of responding fast to the voltage disturbances. For instance, the installation cost of DVR for the power range of 2-10 MVA is USD 300/kVA, yet the installation cost of Uninterruptible Power Supply (UPS) is USD 500/kVA.

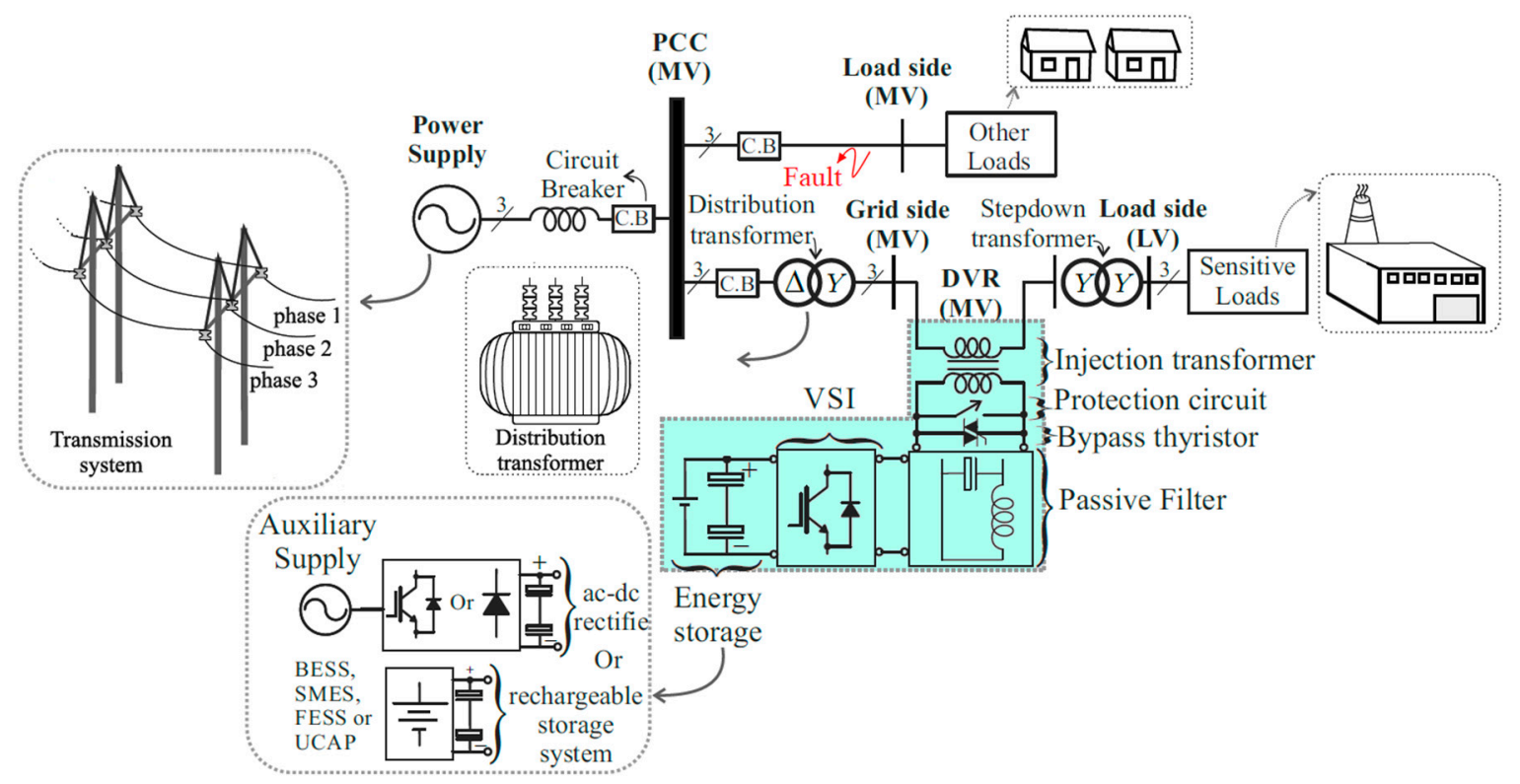

Figure 1. Schematic diagram of the Dynamic Voltage Restorer (DVR) system in the medium voltage distribution network.

The maintenance and operation costs of DVR are about $5 \%$ of its initial cost, but this value is considerably more (about 15\%) [3]. UPQC is a combination of DSTATCOM and DVR in which two power converters are used. Therefore, from the viewpoint of structure, the DVR is smaller than UPQC. DVR and DSTATCOM are similar, but DVR can protect sensitive loads from supply disturbances, and DSTATCOM protects such loads against disturbances of the load side. Plus, the DVR usually responds to voltage disturbances quite fast (less than $1 / 4$ cycle), as opposed to the other CPDs like Static VAR Compensator (SVC) (2-3 cycles) [13].

For improving the power quality, reducing the cost, and enhancing the DVR's performance, many DVR topologies from the different viewpoints of the energy storage, power converter, and control system have been studied.

Moreover, modifying the DVR topology and the integration of renewable energy resources with the DVR has become more popular. Some general reviews on the DVRs have been provided that lack an in-depth study on modified configurations of DVR and its integration with renewable energy technologies [14-16]. A comprehensive review of different DVR topologies, the modified 
DVR topologies, and also the integration of distributed generations with DVR will serve as an extensive reference for those researchers and engineers who are working on power quality issues and voltage disturbance mitigation. The significant contribution of this work is to provide a detailed review on the most critical aspects of the DVR, like principles, operation modes, components, different topologies of DVR from the viewpoint of energy storage, power converters, control units, compensation methods, modulation strategies, and also modified configurations and DVR integration with distributed generation.

The organization of this paper is as follows. The power quality issues, standards, classifications, causes, and effects are provided in Section 2. Additionally, the most crucial custom power devices and their applications are elucidated. In Section 3, the principle of DVR and its different operation modes are described. The components of the DVR power circuit such as injection transformer, energy storage unit, voltage source inverter, filter, and bypass switch are presented in Section 4. DVR topologies from the viewpoint of energy storage are studied in Section 5. In Section 6, different single-/three-phase DVR power converter topologies are discussed. Following this, DVR control units, including voltage disturbance detection methods, reference generation, voltage and current control, and modulation strategies are reviewed in Section 7. Finally, different DVR-modified configurations along with distributed generation integration with DVR are provided in Section 8 , followed by the conclusions along with scopes for future work in Section 9.

\section{Power Quality}

Power quality has become a significant concern for electricity providers and their customers. From the customers' viewpoint, the financial repercussions of disturbances can be hundreds of dollars to millions of dollars in generation loss. From the viewpoint of utilities, disturbances bring about customer satisfaction loss and also load and revenue losses. In general, any deviation from the normal of a voltage source can be categorized as a power quality issue. Power quality issues can be rapid events such as voltage impulses, voltage transients, high-frequency noise, faults, voltage swells/sags, and total power loss. Thus, power quality issues have a direct effect on electrical equipment [17-19]. The disturbances that may cause power quality issues can be lightning and natural phenomena, energization of capacitor banks and transformers, start-up or switching of large loads like motors, operation of non-linear and unbalanced loads, or failure of equipment like transformers and cables.

IEEE and IEC are the two primary standards related to power quality issues. The newest revisions of these standards are provided in Table 1 [20-29]. The classification of power quality issues based on IEEE 519 standards is shown in Figure 2 [20]. The most critical power quality issues, their definitions, causes, and effects are provided in Table 2, along with their duration and magnitude in Table 3 [20-29].

Table 1. All standards associated with power quality issues. Based on data from [20-29].

\begin{tabular}{cc}
\hline Power Quality Standard & Power Quality Issue \\
\hline IEEE 519 [20] & Current and voltage harmonic limitation \\
IEC 61000-3-2 [21] & $\begin{array}{c}\text { Current harmonic limitation (devices with input current } \leq \text { 16 A) } \\
\text { Current harmonic limitation (devices with input current }>\text { 16 A) } \\
\text { IEC/TS 61000-3-4 [22] }\end{array}$ \\
IEEE 141 [23] & $\begin{array}{r}\text { Maintenance and preservation of property, reliability, simplicity, } \\
\text { voltage regulation, flexibility }\end{array}$ \\
IEEE 1159 [24] & $\begin{array}{r}\text { Monitoring and definition of power quality in Alternating Current } \\
\text { (AC) power systems, its impact on customer devices }\end{array}$ \\
IEEE 1250 [25] & Voltage disturbances in AC systems, their impact on sensitive \\
devices, harmonic limitation
\end{tabular}




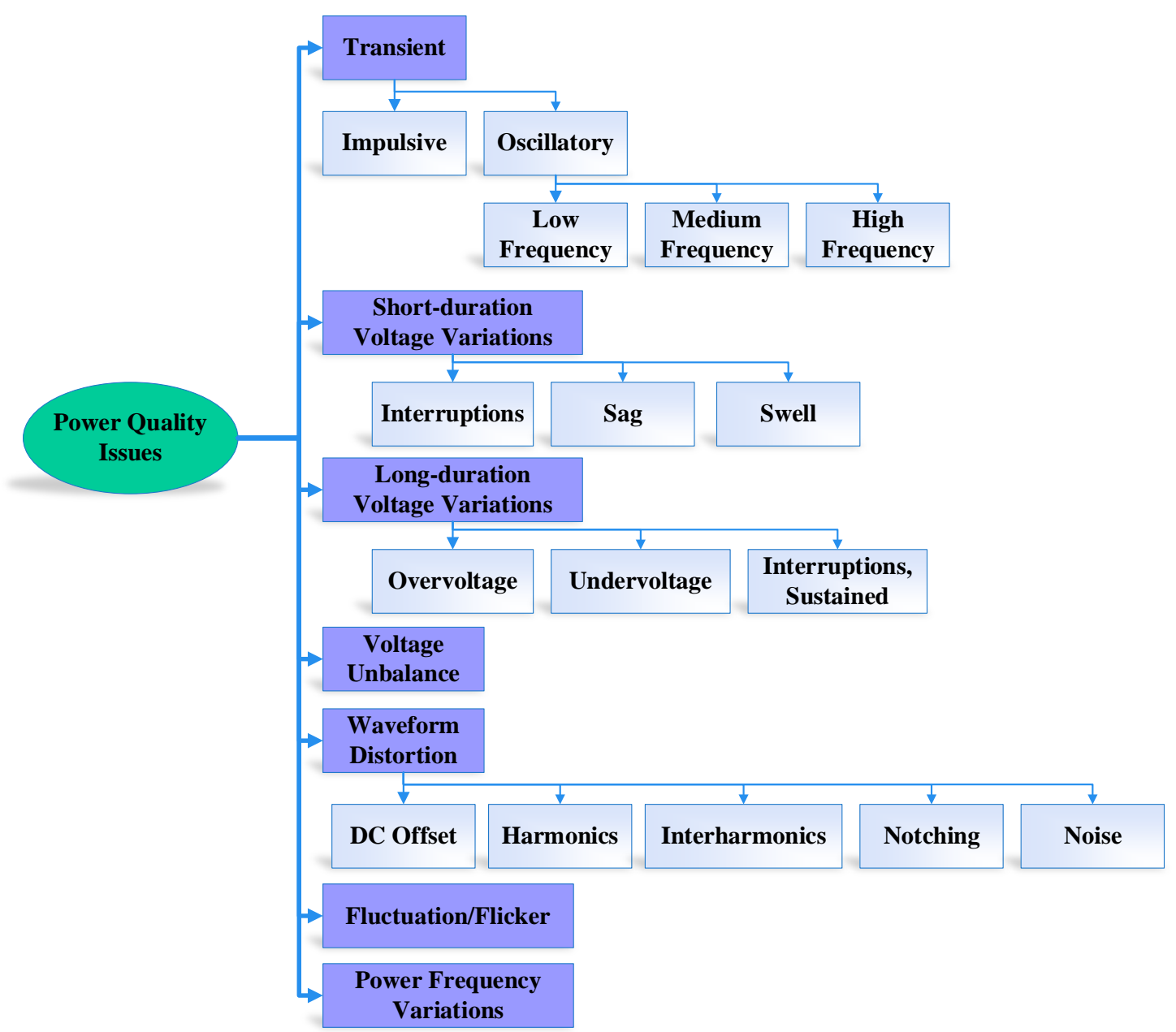

Figure 2. Classification of power quality issues. Based on data from [20].

Table 2. Power quality issues and their definitions, causes, and effects. Based on data from [20-29].

\begin{tabular}{|c|c|c|c|}
\hline Problem & Definition & Causes & Effects \\
\hline Voltage sag/dip & $\begin{array}{l}\text { A decrease in Root-Mean-Square } \\
\text { (RMS) voltage }\end{array}$ & $\begin{array}{l}\text { Faults, starting of large loads, grid } \\
\text { loading, supply voltage variations, } \\
\text { inrush current, } \\
\text { inaccurate connection }\end{array}$ & $\begin{array}{l}\text { Overloading or stalling of } \\
\text { motors, lock-up, } \\
\text { unreliable data }\end{array}$ \\
\hline Voltage swell/rise & An increase in RMS voltage & $\begin{array}{l}\text { Start/stop of heavy loads, supply } \\
\text { voltage variation, inrush current, } \\
\text { inaccurate connection }\end{array}$ & $\begin{array}{l}\text { Data loss, damage to } \\
\text { equipment, lock-up, } \\
\text { unreliable data }\end{array}$ \\
\hline Transient & $\begin{array}{l}\text { An abrupt change in voltage, } \\
\text { current or both }\end{array}$ & $\begin{array}{l}\text { Snubber circuits, lightning, } \\
\text { start/stop of heavy } \\
\text { loads, inaccurate } \\
\text { transformers connection }\end{array}$ & $\begin{array}{c}\text { Disturbance in electrical } \\
\text { equipment, data loss, } \\
\text { the flickering of lights, damage } \\
\text { of sensitive equipment }\end{array}$ \\
\hline Harmonic & $\begin{array}{l}\text { Integral multiples of the } \\
\text { fundamental frequency, resulting } \\
\text { in a distorted voltage or } \\
\text { current waveform }\end{array}$ & Non-linear loads & $\begin{array}{c}\text { Losses in electrical equipment, } \\
\text { transformers and motors } \\
\text { overheating, lock-up, } \\
\text { unreliable data }\end{array}$ \\
\hline $\begin{array}{l}\text { Voltage } \\
\text { fluctuation/flicker }\end{array}$ & $\begin{array}{l}\text { Variations or random alteration in } \\
\text { the voltage magnitude }\end{array}$ & $\begin{array}{l}\text { Load switching, fluctuation of } \\
\text { supply voltage }\end{array}$ & $\begin{array}{l}\text { Over and under voltages, } \\
\text { the flickering of lights, damage } \\
\text { the equipment at the load-side }\end{array}$ \\
\hline $\begin{array}{l}\text { Power } \\
\text { frequency variation }\end{array}$ & $\begin{array}{l}\text { Deviations of the } \\
\text { system frequency }\end{array}$ & Heavy load & $\begin{array}{l}\text { Inefficiency in motors and } \\
\text { sensitive devices, heating up, } \\
\text { gradual breakdown }\end{array}$ \\
\hline Voltage interruption & $\begin{array}{l}\text { A decrease to less than } 0.1 \mathrm{pu} \text { in } \\
\text { supply voltage or load current }\end{array}$ & $\begin{array}{l}\text { Failure of protecting devices, } \\
\text { insulation failure, } \\
\text { control malfunction }\end{array}$ & $\begin{array}{l}\text { Malfunction in data } \\
\text { processing equipment }\end{array}$ \\
\hline
\end{tabular}


Table 3. Duration and magnitude of power quality issues. Based on data from [20-29].

\begin{tabular}{cccc}
\hline Problem & Category & Duration & Magnitude \\
\hline \multirow{2}{*}{ Voltage sag/dip } & Instantaneous & $0.5-30 \mathrm{cycles}$ & $0.1-0.9 \mathrm{pu}$ \\
& Momentary & $30 \mathrm{cycles}-3 \mathrm{~s}$ & $0.1-0.9 \mathrm{pu}$ \\
& Temporary & $3 \mathrm{~s}-1 \mathrm{~min}$ & $0.1-0.9 \mathrm{pu}$ \\
Voltage swell/rise & Instantaneous & $0.5-30 \mathrm{cycles}$ & $1.1-1.8 \mathrm{pu}$ \\
& Momentary & $30 \mathrm{cycles}-3 \mathrm{~s}$ & $1.1-1.4 \mathrm{pu}$ \\
& Temporary & $3 \mathrm{~s}-1 \mathrm{~min}$ & $1.1-1.2 \mathrm{pu}$ \\
& Impulsive (Nanosecond) & $<50 \mathrm{~ns}$ & - \\
Transient & Impulsive (Microsecond) & $50 \mathrm{~ns}-1 \mathrm{~ms}$ & - \\
& Impulsive (Millisecond) & $>1 \mathrm{~ms}$ & - \\
& Oscillatory (Low Frequency) & $0.3-50 \mathrm{~ms}$ & $0-4 \mathrm{pu}$ \\
Harmonic & Oscillatory (Medium Frequency) & $20 \mu \mathrm{s}$ & $0-8 \mathrm{pu}$ \\
Poltage fluctuation/flicker & Oscillatory (High Frequency) & $5 \mu \mathrm{s}$ & $0-4 \mathrm{pu}$ \\
Power frequency variation & - & steady-state & $0-20 \%$ \\
Voltage interruption & - & intermittent & $0.1-7 \%$ \\
& Instantaneous & $<10 \mathrm{~s}$ & \\
& Momentary & $0.5-30 \mathrm{cycles}$ & $<0.1 \mathrm{pu}$ \\
& Temporary & $30 \mathrm{cycles}-3 \mathrm{~s}$ & $<0.1 \mathrm{pu}$ \\
& $3 \mathrm{~s}-1 \mathrm{~min}$ & $<0.1 \mathrm{pu}$ \\
\hline
\end{tabular}

\section{Custom Power Devices (CPDs)}

Storage units are used for critical equipment protection against interruption, leading to voltage sags. Uninterruptible Power Supply (UPS), Superconducting Magnetic Energy Storage (SMES), Ultracapacitors (UCAP), Flywheel Energy Storage System (FESS), and Batteries are some examples of storage systems. These are used to compensate for the energy that is needed because of faults and voltage sags. Among the many different methods of mitigating voltage sags/swells, custom power devices (CPDs) are the most efficient method. Just as Flexible AC Transmission Systems (FACTS) can improve the power quality and stability of the modern power system, CPDs make sure customers receive high quality and reliability of supply [30,31]. The most essential CPDs are provided below. Table 4 provides some of the CPDs' applications for mitigating power quality issues.

Table 4. Custom Power Devices (CPDs) and their functions/applications. Based on data from [30,31].

\begin{tabular}{cc}
\hline CPD & Functions/Applications \\
\hline APF & Transient, harmonic distortion \\
DSTATCOM & Power factor, current harmonics, flicker, load voltage/current balancing \\
DVR & Voltage sags/swells, voltage regulation, flicker, voltage balancing \\
IPFC & Reactive power flow control, transient, voltage control, damping oscillation \\
SSTS & Interruption, voltage sag/swell, power transferring from different feeder \\
SCL, SSCB & Fault current limitation, breaks the faulted circuit \\
STATCOM & Transient, voltage fluctuation/flicker, damping oscillation \\
SSSC & Current control, fault current limitation, active/reactive power flow control \\
SVC & Flicker, unsymmetrical loads \\
SA & Overvoltage, transient \\
TVSS & Voltage transient \\
UPFC & Voltage control, active/reactive power flow control, transient, fault current limitation \\
UPQC & Voltage sags/swells, fluctuations, harmonic, voltage/current balancing, power factor, \\
UPS & current load harmonic \\
\hline
\end{tabular}

Active Power Filter (APF), Battery Energy Storage Systems (BESS), Distribution Static Synchronous Compensator (DSTATCOM), Dynamic Voltage Restorer (DVR), Interline Power Flow Controller (IPFC), Solid-State Transfer Switch (SSTS), Solid-State Circuit Breaker (SSCB), Static Current Limiter (SCL), Static Synchronous Compensator (STATCOM), Static Synchronous Series Compensator (SSSC), 
Static VAR Compensator (SVC), Superconducting Magnet Energy Storage (SMES), Surge Arrester (SA), Transient Voltage Surge Suppressors (TVSS), Unified Power Flow Controller (UPFC), Unified Power Quality Conditioner (UPQC), Uninterruptible Power Supply (UPS).

\section{DVR: Principle}

For the prevention of interruptions caused by voltage sag, particularly in critical loads, the foremost choice is the DVR. The principles of DVR's performance dictate the fact that DVR injects the desired voltage and mitigates every balanced/imbalanced voltage [32]. The DVR supplies its active power from the Direct Current (DC) power supply and therefore injects its reactive power into the system. Moreover, DVR operates in standby mode in normal conditions, unless abnormal conditions occur in the network. The DVR is the supplier of the voltage difference (during voltage sag) between lines and maintain the nominal voltage value at the load-side. By and large, it can be applied to protect critical loads by halting sudden alterations in voltage.

The DVR is composed of injection transformers, protection circuit, bypass thyristor, passive filters, voltage source inverter (VSI), and energy storage (see Figure 1) [33-41]. When a voltage sag/swell happens, the DVR injects a series voltage $\left(V_{i n j}\right)$ into the network via the transformer. Therefore, the magnitude of load voltage can be maintained to its nominal value. The injected voltage is expressed below (Figure 3) [33]:

$$
V_{L}=V_{s}+V_{i n j}
$$

where $V_{L}, V_{S}$, and $V_{i n j}$ are the load, the sagged supply, and the injected voltages, respectively. The load power of each phase under reasonable voltage condition is [33]:

$$
S_{L}=V_{L} I_{L}^{*}=P_{L}-j Q_{L}
$$

where $P_{L}$ and $Q_{L}$ are the active and reactive power of load during sags/swells and $I_{L}$ is the load current. Once the DVR restores the desired voltage to normal, Equation (2) can be expressed as below [33]:

$$
S_{L}=P_{L}-j Q_{L}=\left(P_{s}-j Q_{s}\right)+\left(P_{i n j}-j Q_{i n j}\right)
$$

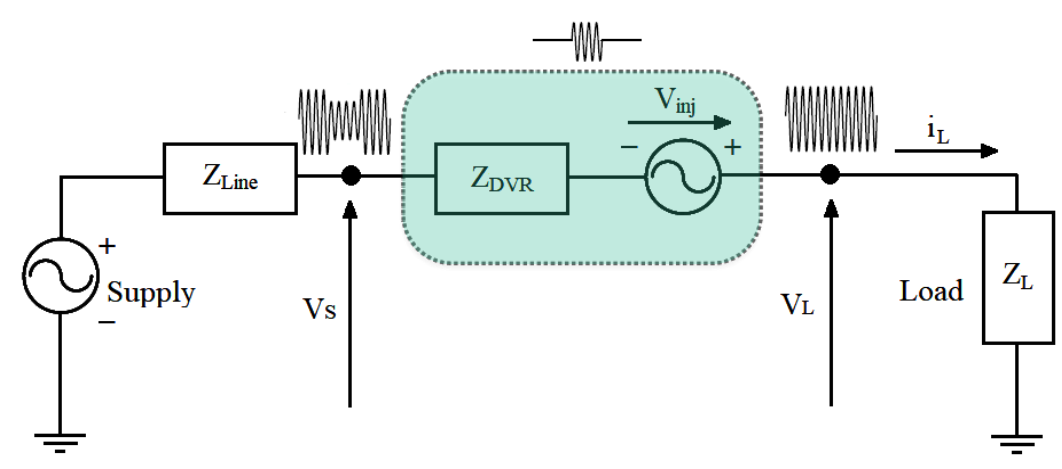

Figure 3. Equivalent circuit diagram of DVR. Based on data from [33].

\subsection{Operation Modes}

The DVR operates in three modes which are the protection mode, the standby mode, and the injection mode.

\subsubsection{Protection Mode}

In this mode of operation, DVR is protected from the high current on the load-side that exceeds an acceptable limit. This high current caused by faults on the load-side can damage the DVR. Thus, the DVR must be protected from such fault currents. An alternative path can do this, which is typically 
made by the breakers and thyristors. Not considering this alternative path causes an overvoltage happening in the injection transformers [42].

\subsubsection{Standby Mode $\left(V_{i n j}=0\right)$}

In this mode of operation, the DVR does not inject voltage because no voltage disturbances are detected. Therefore, the bypass switch bypassed the DVR to prevent any possible little voltage injection. Once a voltage disturbance is identified, the low voltage winding of the injection transformer is short-circuited via the VSI [42,43].

\subsubsection{Injection Mode $\left(V_{i n j}>0\right)$}

In this mode of operation, the DVR switches from the standby mode to this mode if a voltage disturbance is found. Then, the DVR injects the desired voltage through the injection transformer until the voltage is wholly mitigated and returned to its healthy condition [43].

\section{DVR: Power Circuits}

As can be seen in Figure 2, a typical DVR, in general, includes injection transformers, VSI, energy storage unit, passive filters, protection circuits (bypass thyristors).

\subsection{Energy Storage Unit and DC-Link}

The energy storage device and DC-link provide the real power and the required energy of DVR in throughout the compensation stage. This energy storage unit is applied by either AC/DC rectifiers (topology without energy) [44] or rechargeable storage systems (topology with energy storage) [45]. If the grid to which the DVR is connected is not strong enough, the latter topology with technologies like BESS, UCAP, SMES, or FESS is used.

Although BESS has a short lifetime, thereby demanding high maintenance system and increasing the cost of the storage system [46], UCAPs offer a full voltage range, have a shorter charge time and longer lifetime [47]. Thus, using UCAPs is a valid alternative. When the grid is reliable, the voltage which remains on each side (supply or load) is employed to provide the needed voltage of DVR. Thus, AC/DC/AC converters are used in this topology. Different DVR topologies from the viewpoint of energy storage will be discussed in Section 5 .

\subsection{Series Booster/Injection Transformer}

The injection transformers are used to link the DVR to the grid through High Voltage (HV) windings, transforms and couples the injected voltages generated by the VSI to the supply voltage, and isolating the load from the grid. However, there are some topologies in which the DVR has no transformer. This DVR topology is called Transformer-less DVR (TDVR) and has no saturation and inrush current issues. The TDVR topology will be explained in detail in Section 8. The transformers' configuration can be open-delta or open-star $[48,49]$. When a delta-star transformer is used, zero-sequence voltages do not travel through the transformer. As a result, positive and negative sequence voltages have to be compensated. To that end, an open-delta injection transformer that can maximize the use of DC-link voltage is highly recommended. For an earthed star-star transformer, zero-sequence voltages must be compensated. To that end, an open-star injection transformer is used.

\subsection{Voltage Source Inverter}

The VSI is used in the DVR to convert the DC voltage (energy storage or DC-link) to the desired voltage ay any required magnitude, frequency, and phase angle. That way, the load voltage is kept balanced. The voltage generated by the VSI must be injected via the transformers in a controlled way that (1) makes sense. There are several power converter topologies used in the DVR which will be 
described in Section 6. Additionally, different control methods used for power converter topologies in the DVR will be explained in Section 7.

\subsection{Harmonic Filter Unit}

As the output of the inverter contains high-frequency switching harmonics as a result of using high-frequency switching strategies, a low-pass harmonic filter is used to remove or keep these harmonic contents within the acceptable level [50]. These filters can be applied either on the Low Voltage LV (inverter) or the High Voltage HV (load) side of the injection transformer [51]. In the former, high-order harmonics do not propagate into the transformer; in turn, there is no increase in the rating of the transformer. Despite less the voltage stress on the transformer, phase shift, and also voltage sag might happen [52]. Ergo, the perfect design of the filter is a crucial factor when the filter is put on the low-voltage (inverter) side. In the latter, the filter is applied on the load side which means not phase shift, but propagating of harmonics into the HV side of the transformer is possible, resulting in higher rates of transformer [50].

\subsection{Bypass Switch}

In general, a bypass switch is employed as the protection circuit to guarantee an alternative path for the load current, when it comes to faults, overloads, or even maintenance [53]. The reason is that the DVR doesn't always in the injection mode as the voltage disturbances are temporary and occur briefly. If the supply is in a healthy condition, the DVR is in standby mode, so the DVR is bypassed by the bypass switch for protection. Note that the bypass switch has power loss. This power loss happens when the supply is in a normal condition. As the DVR's efficiency is measured when the DVR is in the injection mode, the power loss of the bypass switch can be negligible.

\section{DVR: System Topologies}

Depending on energy storage, or the lack thereof, there are two topologies of the DVR $[7,54]$. Figure 4 shows the categorization of the DVR that has or lack energy storage [7,54].

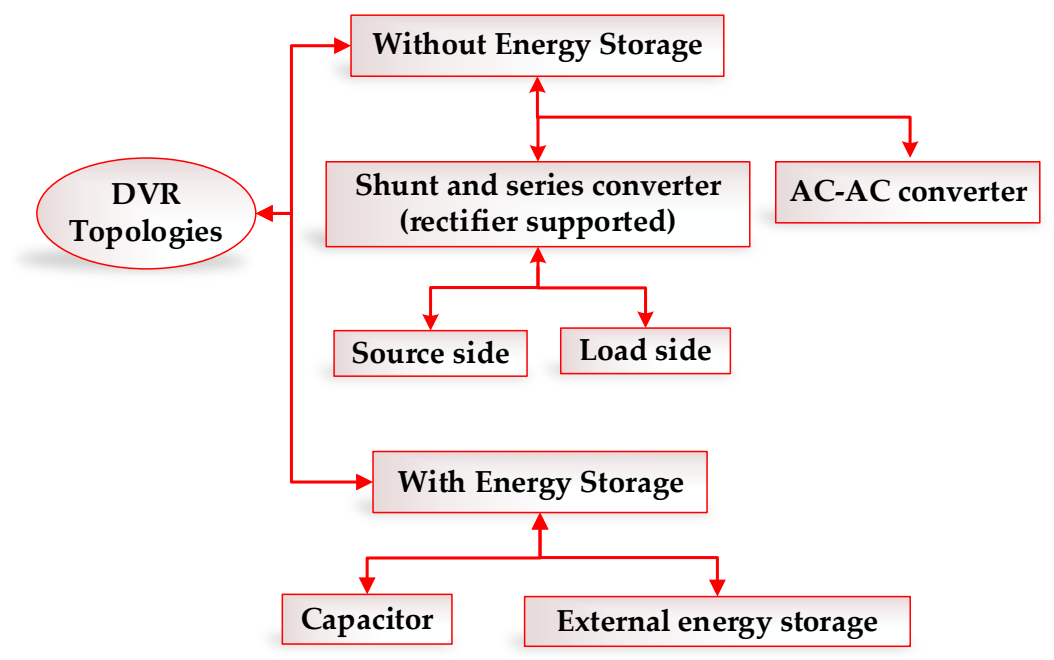

Figure 4. DVR topologies from the energy storage perspective. Based on data from $[7,54]$.

\subsection{DVR Without Energy Storage}

The principle of topologies of DVR without energy storage is that the supply-side provides the desired energy via a power converter linked in parallel to either the supply or load, as shown in Figure $5 \mathrm{a}, \mathrm{b}$, respectively $[7,54]$. In other words, the supply voltage is employed to support energy and keep the load power at its nominal value. The topology without energy storage can be composed of an 
AC/AC power converter or a combined shunt/series power converter. The shunt converter, or primarily rectifier, can be linked to the supply or load.

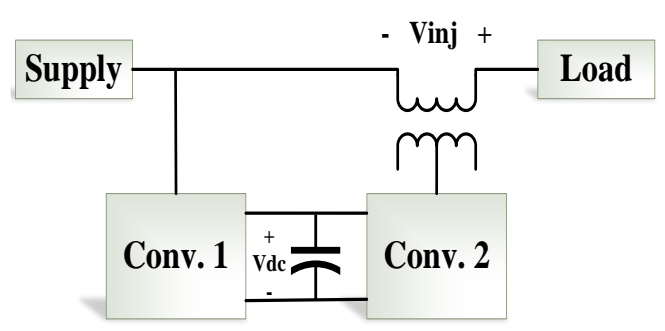

(a)

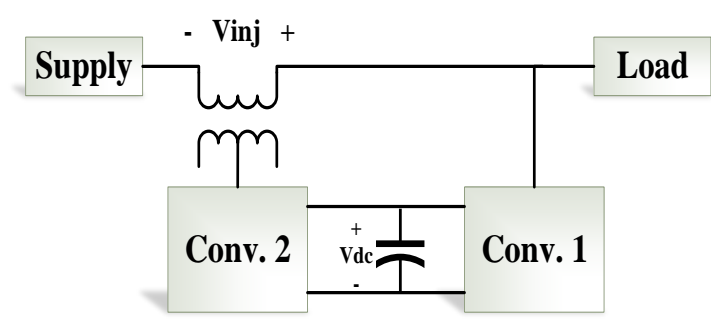

(b)

Figure 5. DVR topologies with no energy storage in (a) supply-side, (b) load-side. Based on data from $[7,54]$.

\subsection{DVR with Energy Storage}

The principle of topologies of DVR with energy storage is that the desired energy is provided by either a DC-link or an external energy storage unit linked to the DC-link, as shown in Figure 6a,b, respectively [7,54]. If a DC-link delivers the desired energy of the DVR, then DC-link can vary. In the following topology, the DC-link voltage is controllable. However, this voltage remains unchanged.

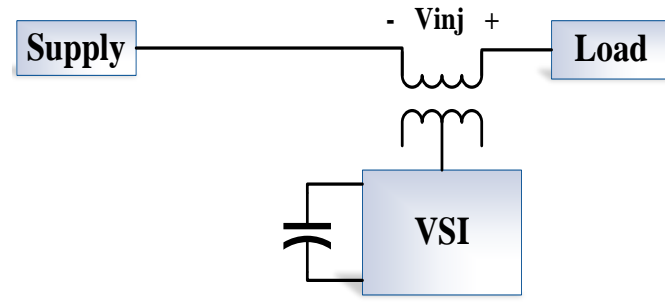

(a)

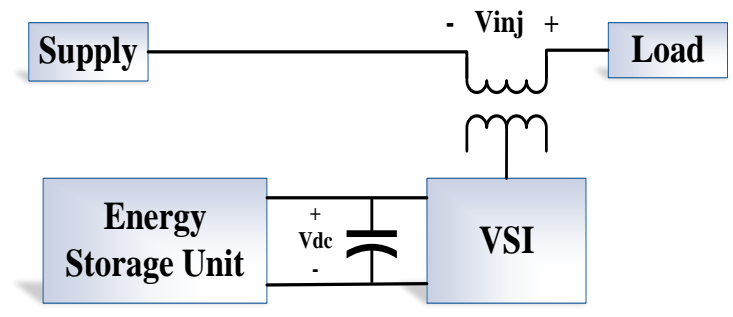

(b)

Figure 6. DVR topologies with energy storage: (a) capacitor, (b) with the external energy storage unit. Based on data from [7,54].

In this DVR topology, the desired energy is saved in the capacitor, when there is no disturbance in the supply. The advantages and disadvantages of both topologies are provided in Table 5 [7,54].

Table 5. The advantages and disadvantages of DVR topologies. Based on data from [7,54].

\begin{tabular}{ccc}
\hline Topology & Advantages & Disadvantages \\
\hline Without Energy Storage & $\begin{array}{c}\text { Saving is achievable; mitigates } \\
\text { longer voltage sag; suitable if the } \\
\text { grid is reliable; controllable input } \\
\text { voltage of the shunt converter; the } \\
\text { load-side connected shunt } \\
\text { converter topology is efficient }\end{array}$ & $\begin{array}{c}\text { Drawing more current during the } \\
\text { voltage disturbance; uncontrollable } \\
\text { DC-Link voltage; limited deep voltage } \\
\text { sags compensation; an increase in the } \\
\text { current and a decrease in input voltage, } \\
\text { during deep drops; load disturbance }\end{array}$ \\
With Energy Storage & $\begin{array}{c}\text { No need for any external energy } \\
\text { storage, cost-effective, the DC-link } \\
\text { voltage is kept constant, suitable if } \\
\text { the grid is weak }\end{array}$ & $\begin{array}{c}\text { The injected voltage (magnitude and } \\
\text { phase angle) must be controlled for } \\
\text { sensitive loads, cannot mitigate } \\
\text { long/deep voltage sags for energy } \\
\text { storage restriction in the capacitor }\end{array}$ \\
\hline
\end{tabular}

\section{DVR: Power Converter Topologies}

From the power converter viewpoint, DVR can be categorized into single-/three-phase DVR topologies (Figure 7) [55-62]. Full-bridge, known as H-bridge, and half-bridge are the most common 
power converters used in single-phase topologies of the DVR. Although direct AC/AC power converters, multilevel inverters (MLIs), and impedance-source inverter (ZSI) families are deployed in single-phase topologies of the DVR, they are mostly utilized for three-phase topologies of the DVRs [55-58]. The power converter topologies used mostly in three-phase DVRs are three full-bridge inverters, four-leg inverters, two-level inverters (four-wire), also split-capacitor two-level inverters [59-62].

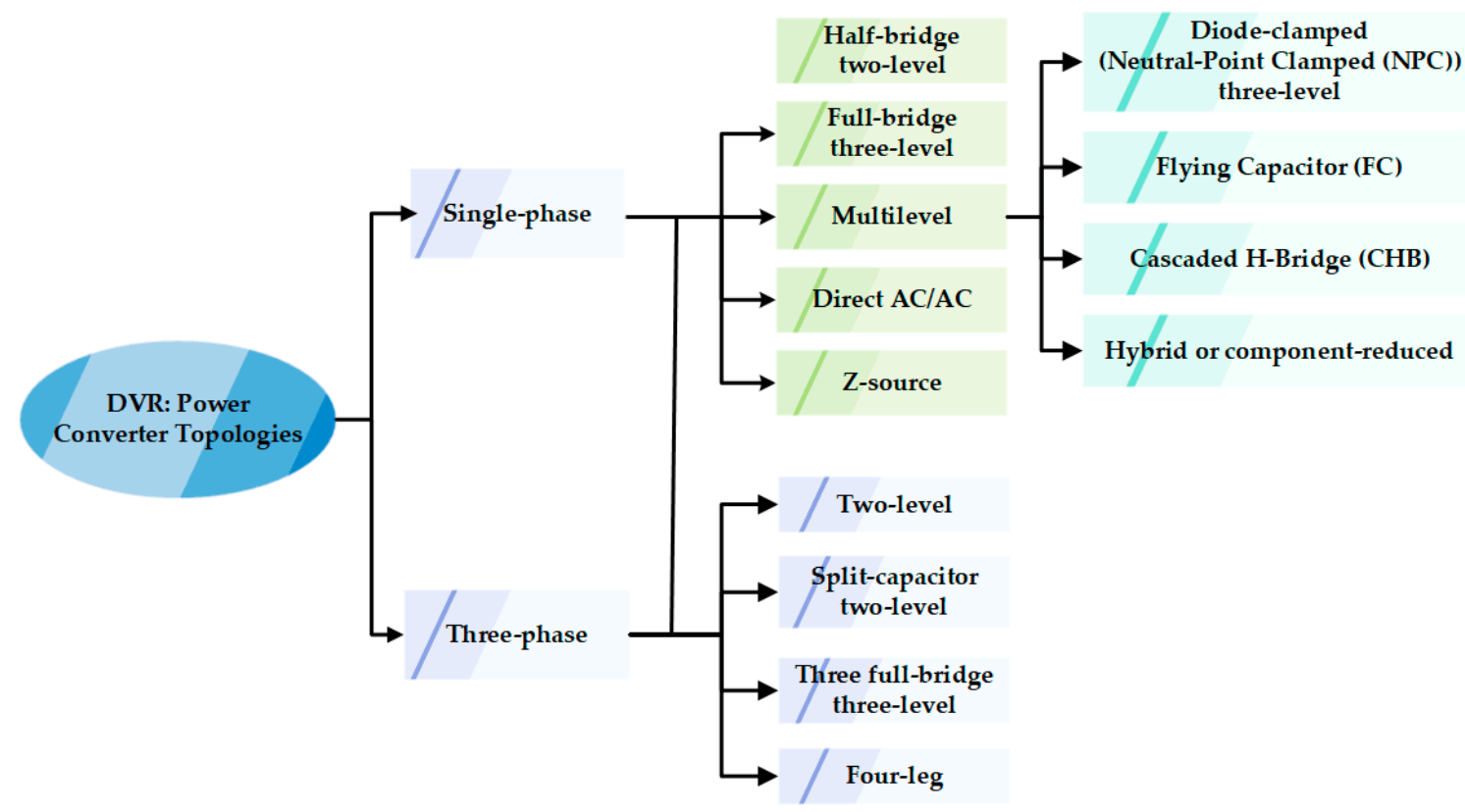

Figure 7. DVR topologies from the power converter perspective. Based on data from [55-62].

For LV grid applications, DVR topologies with two-level power converters are typically used because the switching method-Pulse Width Modulation (PWM) —is simple, and it costs less than MLIs. Two-level power converter topologies cannot be applied for Medium-Voltage (MV) grid applications because of the high voltages on switches, which is why power-electronic devices are typically used in the MV grid connections. One option to address this problem is to employ seriesor parallel-connected switches. However, a better option is employing MLIs. The MLIs have good harmonic characteristics (lower harmonic components), higher power quality, reliable operation at higher voltage levels, and lower switching stress across the switches. The MLIs can be classified into Diode-Clamped MLI (DC MLI) known as Neutral-Point Clamped MLI (NPC MLI), Flying Capacitor MLI (FC MLI), and Cascaded H-Bridge MLI (CHB MLI). The last MLI topology, CHB MLI, is the most renowned one.

In the NPC MLI topology, as the number of voltage level increases more than three, the balancing of capacitors' voltage is far from easy, which is why the three-level NPC MLI is typically used [63-66]. In the FC MLI topology, not only is the selection of switches more flexible but also the voltage balance of capacitors is more controllable. Therefore, the higher voltage level applications are not challenging, as opposed to the NPC MLI topology. However, the FC MLI has a downside that if the voltage level goes up, the number of capacitors goes up [67-69]. The CHB MLI topology, the most common MLI topology as previously mentioned, has a modularity feature, thereby increasing its reliability. The only disadvantage of CHB MLI topology is that isolated DC sources are needed for each H-bridge. One solution is to connect a low-frequency transformer to each $\mathrm{H}$-bridge output. By doing so, rather than using several isolated DC sources, one DC source is used [53,70-78]. Other hybrid or modified MLI topologies, aside from the MLI mentioned above topologies, have also been presented in DVR [79-81]

It should be pointed out that apart from the advantages mentioned above of MLIs, they have a disadvantage of requiring a surplus of clamping diodes, switches, and energy storage units based on the MLI's type. 
One of the power converter topologies of the DVR is AC/AC converters which can be in unique structures like direct, matrix, and ZSI [82-93]. In this topology, there is no need for DC-link and energy storage. This is the main outstanding advantage of DVRs with AC/AC power converter topology, which results in lower weight, volume, and cost. The elimination of DC-link and energy storage units can also increase the reliability of topology. Moreover, this topology can compensate and mitigate prolonged voltage disturbances. Like other topologies, this topology has some disadvantages. To cite a few, the operation of bidirectional semiconductor switches is not smooth as they are used primarily in this topology. Plus, voltage drops can occur on the line as more current must be drawn from the grid for providing the load with equal power. This drawback exists in topologies that have no energy storage, and chances are the current exceeds the line limits. Therefore, the AC/AC power converter topology cannot compensate and mitigate deep sags, mainly when the DVR is linked to a weak network.

The DVR topologies from the power converter (three-phase) perspective, along with their merits and demerits are provided in Table 6 [82-93]. Figure 8 illustrates three-phase power converter topologies of DVR based on the two-level inverter, split-capacitor two-level inverter, three full-bridge inverters, and ZSI [82-93]. Note that Figure $8 \mathrm{c}$ shows the transformer connected DVR with three full-bridge inverters. The transformer-less DVR (TDVR) with three-phase full-bridge inverters will be explained and shown in Section 8.

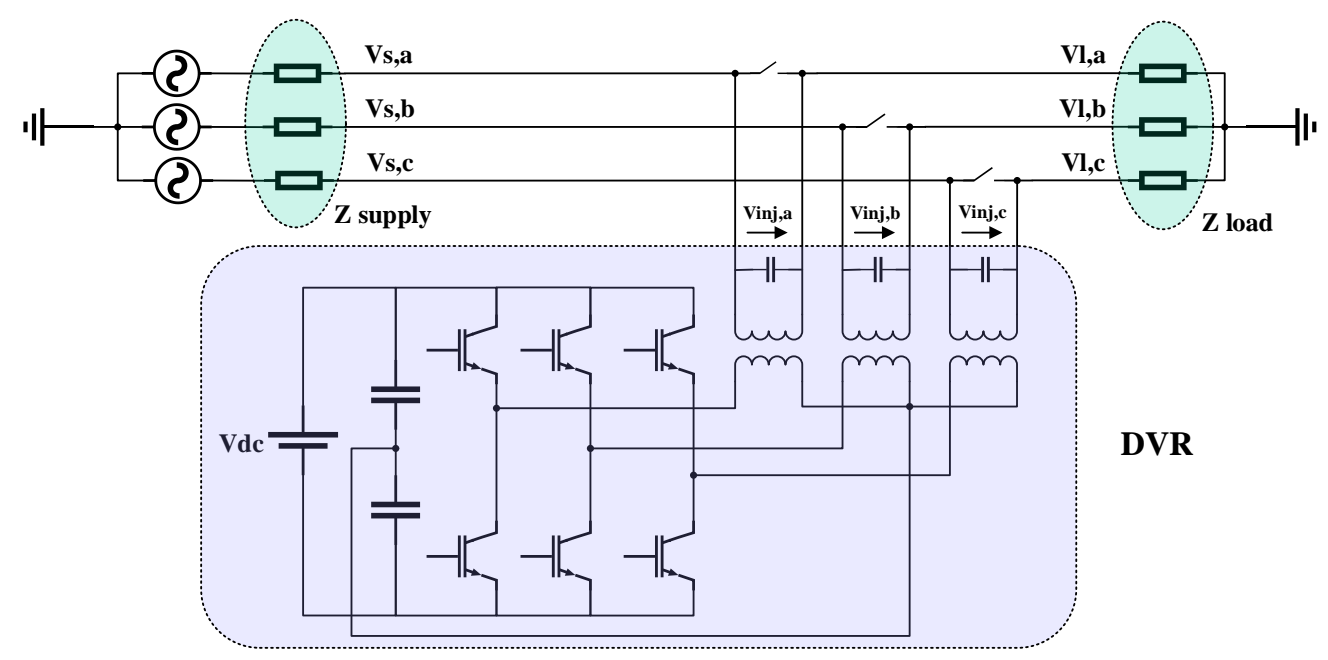

(a)

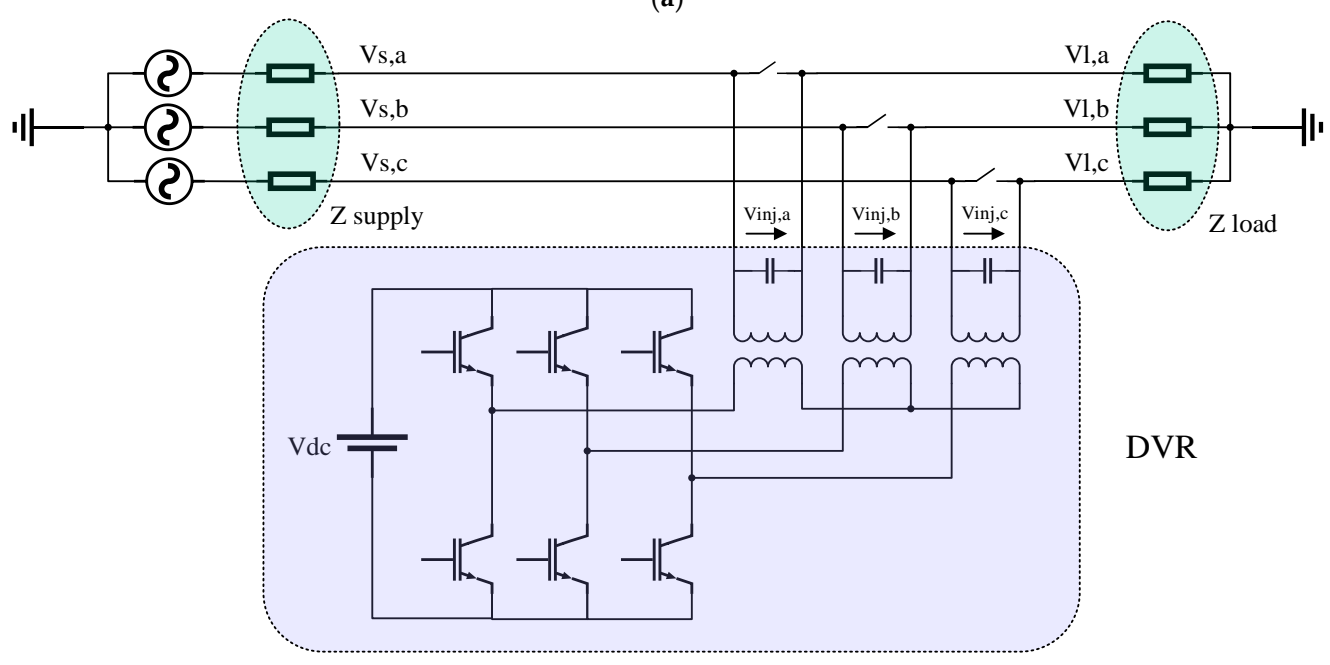

(b)

Figure 8. Cont. 


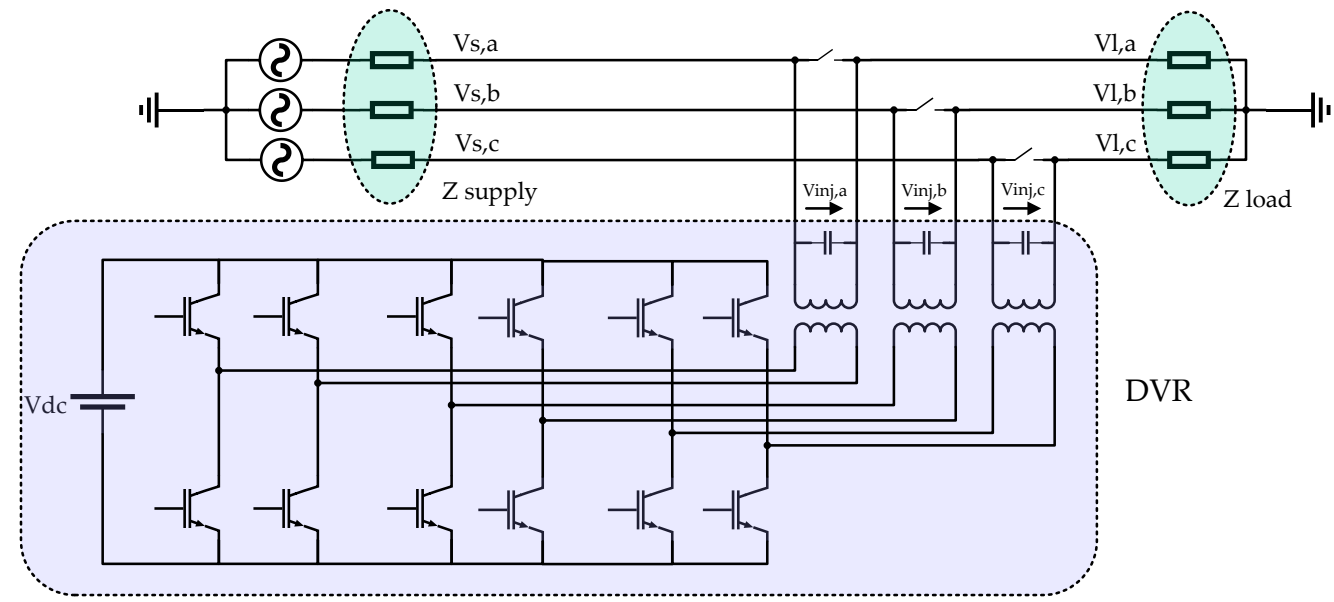

(c)

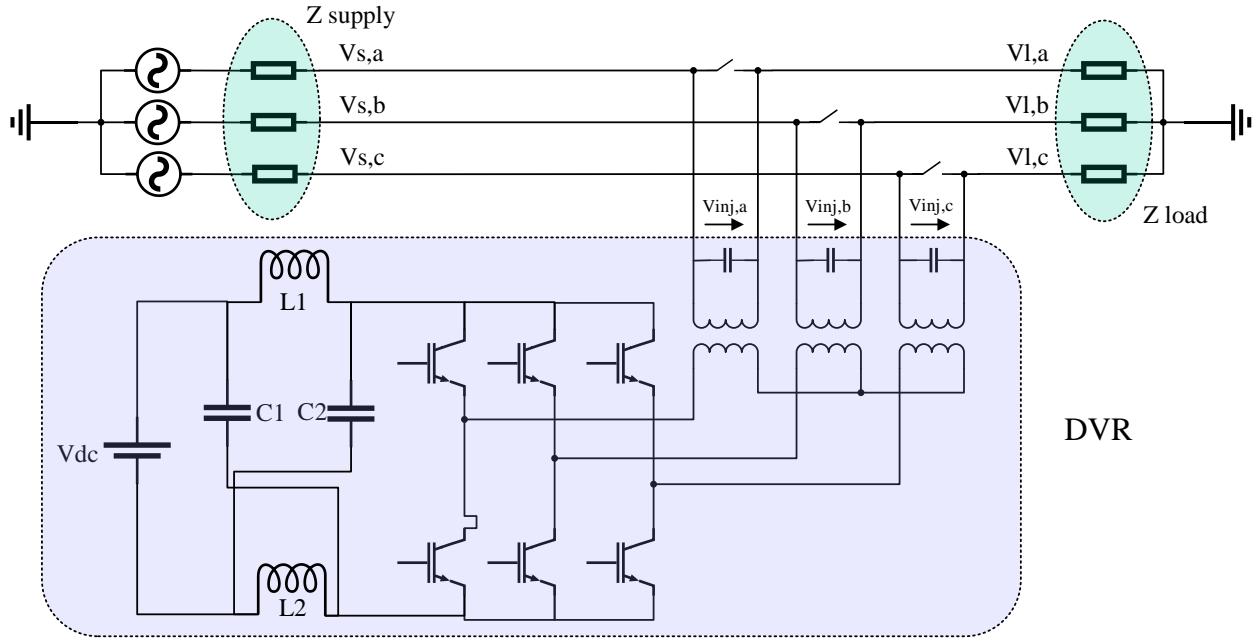

(d)

Figure 8. Three-phase power converter topologies of Dynamic Voltage Restorer (DVR) based on (a) two-level inverter, (b) split-capacitor two-level inverter, (c) three full-bridge inverters, and (d) impedance-source inverter (ZSI). Based on data from [82-93].

Table 6. Three-phase power converter topologies of DVR, advantages, and disadvantages. Based on data from [82-93].

\begin{tabular}{|c|c|c|}
\hline Topology & Advantages & Disadvantages \\
\hline $\mathrm{AC} / \mathrm{AC}$ converter & $\begin{array}{c}\text { Elimination of DC-link/energy storage extended } \\
\text { voltage disturbance mitigation }\end{array}$ & $\begin{array}{c}\text { Fails to mitigate deep voltage sag } \\
\text { in a weak grid }\end{array}$ \\
\hline \multirow{3}{*}{ MLI } & Multilevel output voltage & $\begin{array}{l}\text { Limited to three-level, requires } \\
\text { clamping diodes }\end{array}$ \\
\hline & Increased output voltage levels & $\begin{array}{l}\text { Requires flying capacitors, } \\
\text { charging restrictions }\end{array}$ \\
\hline & Modularity, higher reliability & Requires several DC sources \\
\hline ZSI & $\begin{array}{c}\text { Deep sags mitigation, lower DC-link voltage, } \\
\text { higher voltage gain, lower voltage stress across } \\
\text { the switches }\end{array}$ & Extra passive components \\
\hline Two-level inverter (four-wire inverter) & $\begin{array}{l}\text { Simple, lower cost (fewer } \\
\text { semiconductor switches) }\end{array}$ & $\begin{array}{l}\text { Fails to mitigate unbalanced } \\
\text { voltage disturbances }\end{array}$ \\
\hline Split-capacitor two-level inverter & $\begin{array}{l}\text { Simple, lower cost (fewer semiconductor } \\
\text { switches), mitigation of unbalanced } \\
\text { voltage disturbances }\end{array}$ & $\begin{array}{l}\text { Hard to balance capacitors' } \\
\text { voltage, the lower output voltage }\end{array}$ \\
\hline Three Full-bridge (H-bridge) inverters & Mitigation of unbalanced voltage disturbances & More semiconductor switches \\
\hline Four-leg inverter & $\begin{array}{l}\text { Mitigation of unbalanced voltage disturbances, } \\
\text { lower DC-link voltage ripples }\end{array}$ & $\begin{array}{l}\text { More semiconductor switches, } \\
\text { the higher switching frequency }\end{array}$ \\
\hline
\end{tabular}




\section{DVR: Control Unit}

Controlling the magnitude, frequency, and phase angle is the primary function of the control unit in DVR as an essential part of DVR. The control unit has several stages from selecting the operation mode and detecting the voltage disturbance to pulse generation for VSI and injecting the desired voltage. Figure 9 depicts different stages of the control unit in DVR.

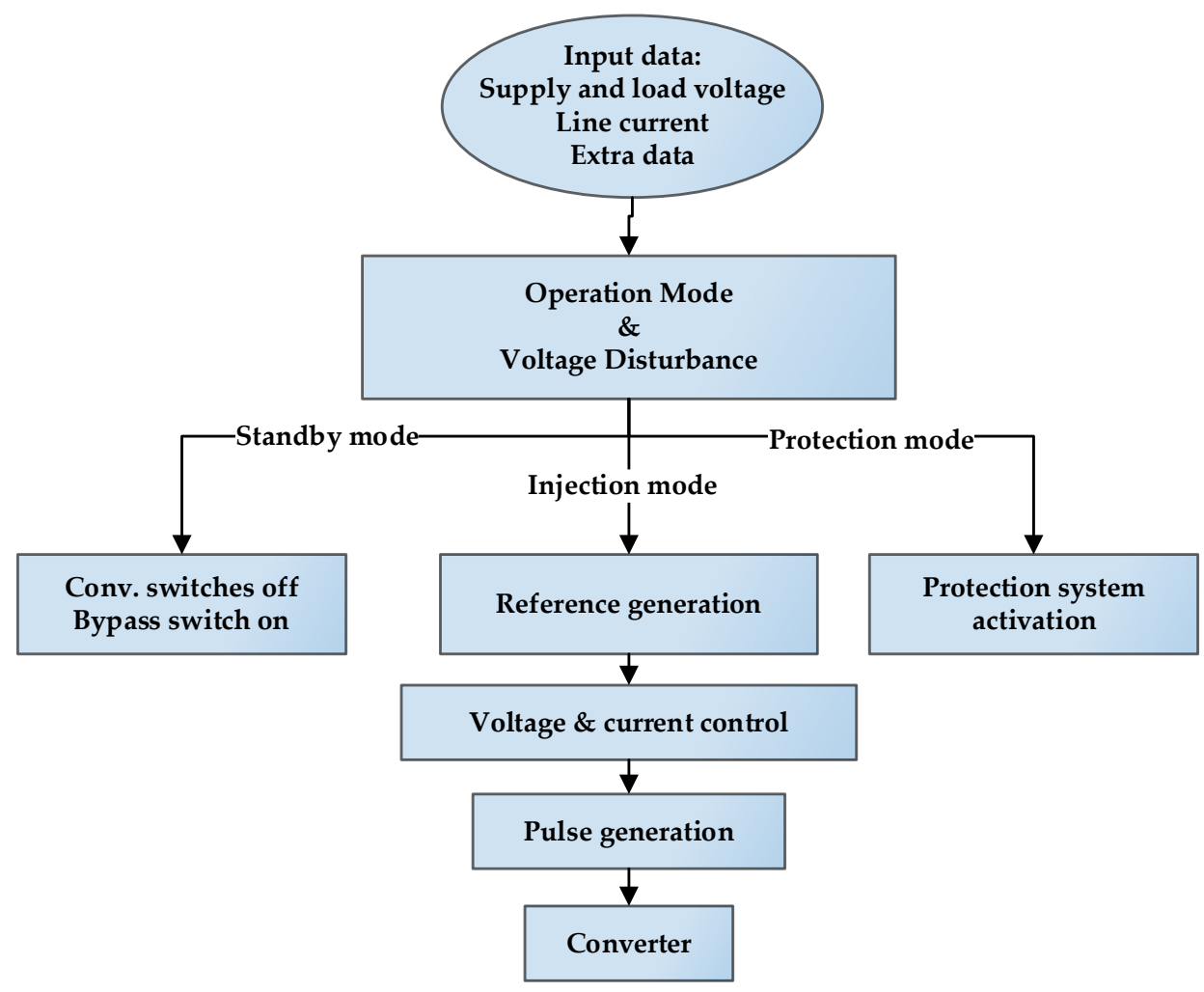

Figure 9. Different stages of the control unit in the DVR. Based on data from $[7,42,69,94-170]$.

First off, the input data, including load- and supply-side voltage, line current, and supplementary information like the nominal voltage, must be collected. The voltage and current values of each side (supply/load) are delivered to the operation mode and voltage disturbance system. This system has to determine what the DVR operation mode is. As previously described in Section 5, the DVR's operation mode can be protection, standby, and injection.

If the standby mode is determined, the bypass switch is turned on, and all the converter semiconductor switches are turned off. If the fault current decreases, then the DVR operation mode switches to protection mode. Based on the measured voltage, the voltage disturbance detection system detects the disturbance type like voltage sag/swell or harmonic. Thus, if a voltage sag or swell is identified, then the DVR operation mode switches to the mode of compensation, thereby generating the reference voltages. This system is to generate the desired voltage that is needed for injection by the DVR. Either an open-loop and closed-loop control can be used. If the former is used, the reference generation system's output is separated by the DC-link to generate reference voltages. If the latter is used, which happens to be more preferable, the generation system's output supplies the voltage and current controllers. Thus, the controller's output is the reference voltage. Finally, it is designated to the modulation to create switching pulses of the VSI.

Several different methods have been introduced and presented for every abovementioned stage of the control unit in the DVR. The most commonly used methods for every stage are illustrated in Figure $10[7,42,69,94-170]$. 


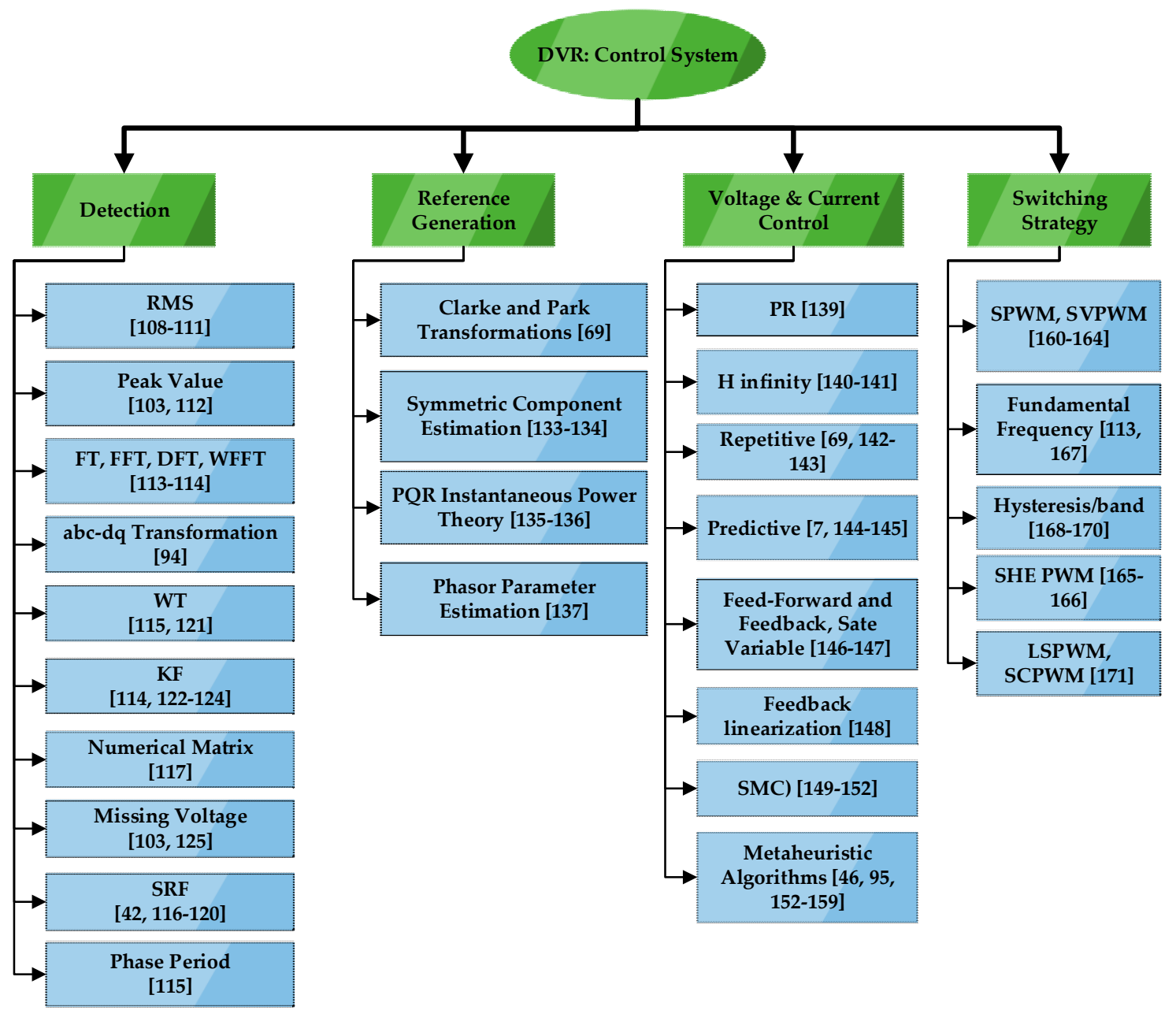

Figure 10. The most commonly used methods in the DVR's control unit. Based on data from $[7,42,69,94-170]$.

\subsection{Voltage Disturbance Detection Methods}

The first stage in the control unit of the DVR is the detection of voltage disturbances. The detection system plays a crucial role when it comes to sensitive loads. This means that quick and accurate voltage disturbance detection is of vital importance for DVR performance. As can be seen in Figure 10, several methods have been presented for voltage disturbance detection [94-107] like Root Mean Square (RMS), Peak Value, Fourier Transform (FT), Discrete FT (DFT), Windowed Fast FT (WFFT), $a b c-d q$ Transformation, Wavelet Transform (WT), Kalman Filter (KF), and Phase-Locked Loop (PLL), and Synchronously Rotating Frame (SRF). The advantages and disadvantages of the most critical voltage disturbance detection methods are provided in Table 7. Some of them are described below.

The traditional methods like RMS method or Peak Value, the RMS variation, or peak voltage variation is measured to detect voltage disturbance. In the RMS method, the start-/end-points of voltage disturbance are detected by RMS measurement of supply voltage and then comparing with the initial reference value. Usually, a threshold voltage value is specified. If the difference between the RMS and the initial reference values is exceeded, a voltage disturbance exists. The advantage of the RMS method is its simplicity; however, it cannot operate fast. Therefore, the RMS method is not appropriate for DVR applications. 
Table 7. Voltage disturbance detection methods, their advantages, and disadvantages.

\begin{tabular}{|c|c|c|}
\hline Detection Method & Advantages & Disadvantages \\
\hline RMS [108-111] & $\begin{array}{l}\text { Detects start-/end-points of sags/swells, simple, } \\
\text { fast, less memory }\end{array}$ & $\begin{array}{l}\text { Fails to identify the fundamental } \\
\text { frequency and harmonic, fails to } \\
\text { detect phase angle shifts }\end{array}$ \\
\hline Peak Value $[103,112]$ & $\begin{array}{l}\text { A quarter cycle delay in detecting sags/swells } \\
\text { (up to half a cycle), sags/swells depth, } \\
\text { start-/end-points }\end{array}$ & $\begin{array}{l}\text { Ignoring noise signals, hard to } \\
\text { extract phase shift angle data }\end{array}$ \\
\hline DFT $[113,114]$ & Sags/swells detection, harmonic distortion & $\begin{array}{l}\text { Needs stationary signal, integer } \\
\text { sample numbers, high } \\
\text { computations (needs one complete } \\
\text { cycle for accurate sag/swell depth } \\
\text { and phase data), detection delay }\end{array}$ \\
\hline FFT [114] & $\begin{array}{l}\text { Faster than DFT, detects phase angle shifts, } \\
\text { harmonic distortion, accuracy }\end{array}$ & $\begin{array}{l}\text { Needs stationary signal, integer } \\
\text { sample numbers }\end{array}$ \\
\hline PLL [115] & Sags/swells detection, phase angle shifts & $\begin{array}{l}\text { Needs time delay up to half-cycle, } \\
\text { hard to control }\end{array}$ \\
\hline SRF $[42,116-120]$ & Suitable for three-phase systems & $\begin{array}{l}\text { Very short time detection, } \\
\text { unsuitable for single-phase } \\
\text { systems, fails to detect the } \\
\text { unbalance voltage sags/swells }\end{array}$ \\
\hline WT $[115,121]$ & Availability of data frequency and time & $\begin{array}{c}\text { Needs proper selection of wavelet } \\
\text { prototype, maybe need a delay } \\
\text { related to wavelet prototypes }\end{array}$ \\
\hline KF $[114,122-124]$ & $\begin{array}{l}\text { Optimum detection of voltage sags/swells, } \\
\text { strong performance with linear systems }\end{array}$ & $\begin{array}{l}\text { Needs improved KF for } \\
\text { non-linear systems }\end{array}$ \\
\hline Period Phase [115] & $\begin{array}{l}\text { Detects any variation in voltage RMS, phase } \\
\text { angle shift, start-/end-points of sags/swells, fast, } \\
\text { suitable for single- and three-phase systems }\end{array}$ & - \\
\hline Numerical Matrix [117] & $\begin{array}{l}\text { Fast sags/swells depth and phase angle shift } \\
\text { detection, available disturbance data }\end{array}$ & - \\
\hline Missing Voltage $[103,125]$ & $\begin{array}{l}\text { Fast detection, start-/end-points of sags/swells, } \\
\text { reliable sags/swells compensation data }\end{array}$ & - \\
\hline
\end{tabular}

However, advanced methods outperform conventional methods. The FT method provides data on depth and phase shift of sags, magnitude, and phase of supply, in particular when the supply voltage has harmonics. Like the RMS method, this method is not fast.

The WT method finds the start/end-points of sag by an analysis of the wavelet transform coefficient. The WT method, however, requires the proper selection of wavelet prototype for accurate detection. Although this method operates faster in the detection of any alteration in supply voltage phases, it has some disadvantages. The information provided by the WT method can be far from easy to convey. Additionally, there may be a delay regarding wavelet prototypes.

Another method is $a b c-d q$ transformation. To detect voltage disturbances in this method, $V_{d}$ is compared with the reference value. The advantage of this method is that it is so fast and straightforward to implement. The drawback of this method is that it may not perform adequately with unbalanced voltage disturbances. In imbalanced voltage sags, the positive/negative sequence's elements of supply voltage are singled out, thereby employing the transformation for each one individually. This transformation must be adjusted. To that end, a PLL is used which can provide data on the supply voltage. Note that the voltage data in this paper are considered as its magnitude and phase angle to avoid repetition.

Once the voltage disturbance is detected, the reference voltage data should be provided. Depending on the voltage compensation method, the injected voltage data vary. The voltage compensation method may mitigate just one of the voltage data or both of them simultaneously. The following section will describe different voltage compensation methods. 


\subsection{Voltage Compensation Methods}

Depending on the DVR power rate, load types, conditions, fault types, etc., the voltage compensation method is chosen. This is mainly because some loads are very sensitive to phase angle jump, and some are not. There are four voltage injection/compensation strategies $[126,127]$.

\subsubsection{Pre-Sag Compensation Method}

This method always tracks the supply voltage all the time to detect any voltage disturbances, thereby generating and injecting the difference voltage. That way, the load voltage is kept unaltered as the pre-sag voltage. The pre-sag compensation method is capable of restoring the sensitive load voltage to the same phase angle and magnitude as the nominal pre-sag voltage. This method is recommended for non-linear loads which are very sensitive to phase angle jumps. This requires a higher rating of the DVR. Moreover, the DVR in this method supplies active/reactive power both from the VSI. However, high capacity energy storage is needed as no control of the active power during the compensation stage exists [103,128-131].

The phasor diagram of the pre-sag compensation method is shown in Figure 11a [129]. Note that here, $V_{s-s a g}, V_{L-s a g}, V_{i n j}$ and $I_{L-s a g}$ remark variables after the sag, and $V_{S}, V_{L}$ and $I_{L}$ are related to the variables before the sag. Plus, $\alpha$ is the phase angle difference between the load current and voltage, and $\beta$ is the phase jump of supply voltage throughout the sag. The active power between the DVR and supply, the magnitude, and phase angle of injected voltage are provided in (4)-(6), respectively [129].

$$
\begin{gathered}
P_{i n j}=P_{L}-P_{s}=\left(3 \cdot V_{L} \cdot I_{L} \cdot \cos (\alpha)-\sum_{j=a, b, c}\left(V_{s-s a g, j} \cdot I_{L} \cdot \cos \left(\alpha-\beta_{j}\right)\right)\right) \\
V_{i n j, j}=\sqrt{2} \cdot \sqrt{\left(V_{L}\right)^{2}+\left(V_{s-s a g, j}\right)^{2}-2 \cdot V_{L} \cdot V_{s-s a g, j} \cdot \cos \left(\beta_{j}\right)} \\
\angle V_{i n j, j}=\tan ^{-1}\left(\frac{V_{L} \cdot \sin (\alpha)-V_{s-s a g, j} \cdot \sin \left(\alpha-\beta_{j}\right)}{V_{L} \cdot \cos (\alpha)-V_{s-s a g, j} \cdot \cos \left(\alpha-\beta_{j}\right)}\right)
\end{gathered}
$$

where $V_{i n j, j}$ is the line-to-neutral supply voltage (RMS) in phase $j, V_{L}$ is the line-to-neutral load voltage (RMS), and $\beta_{j}$ is the phase jump in phase $j$.

\subsubsection{In-Phase Compensation Method}

In this method, the injected and the supply voltages are in-phase with one another. As the injected voltage magnitude is minimized [34], the voltage rating of the DC-link or storage unit is marginal. This method requires compensation for active power. Plus, it is just able to mitigate the magnitude of load voltage, not its phase jump. As phase jumps happen in most voltage sag cases, this method is not appropriate for sensitive loads. However, the in-phase compensation method is suitable for linear loads that the voltage magnitude is important. Figure $11 \mathrm{~b}$ depicts the phase diagram of this method [129].

$$
\begin{gathered}
P_{\text {inj }}=P_{L}-P_{s}=\left(3 \cdot V_{L} \cdot I_{L} \cdot \cos (\alpha)-\sum_{j=a, b, c}\left(V_{s-s a g, j} \cdot I_{L} \cdot \cos (\alpha)\right)\right) \\
V_{i n j, j}=\sqrt{2} \cdot\left|V_{L}-V_{s-s a g, j}\right|
\end{gathered}
$$




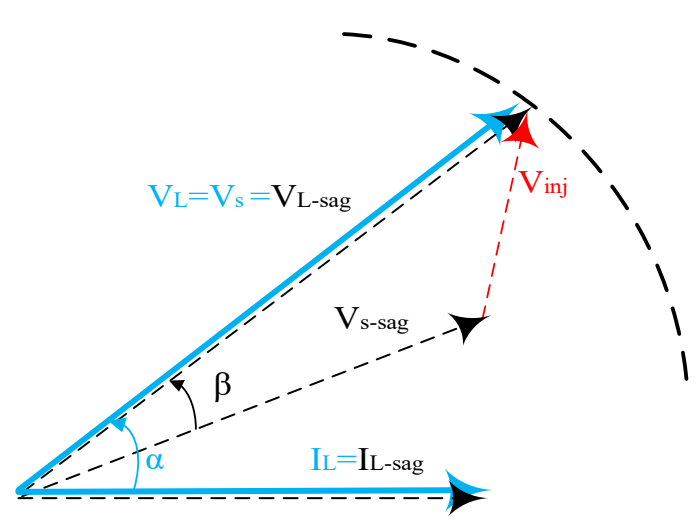

(a)

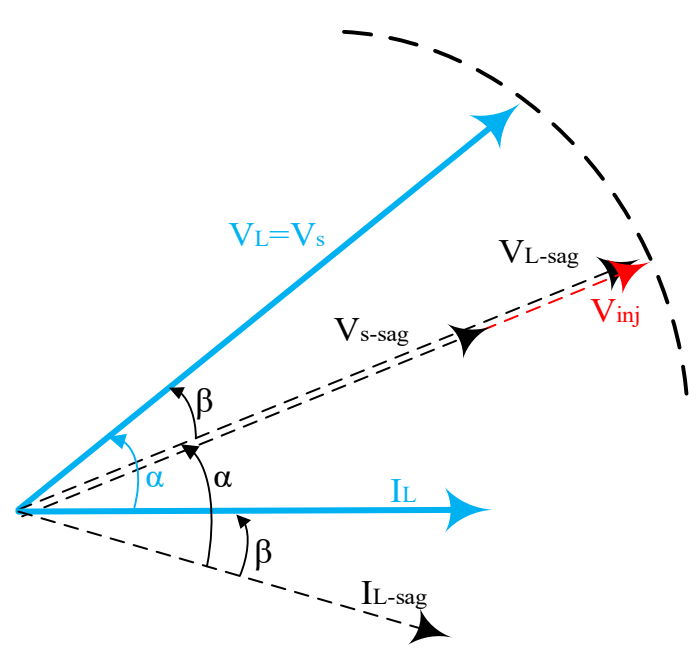

(b)

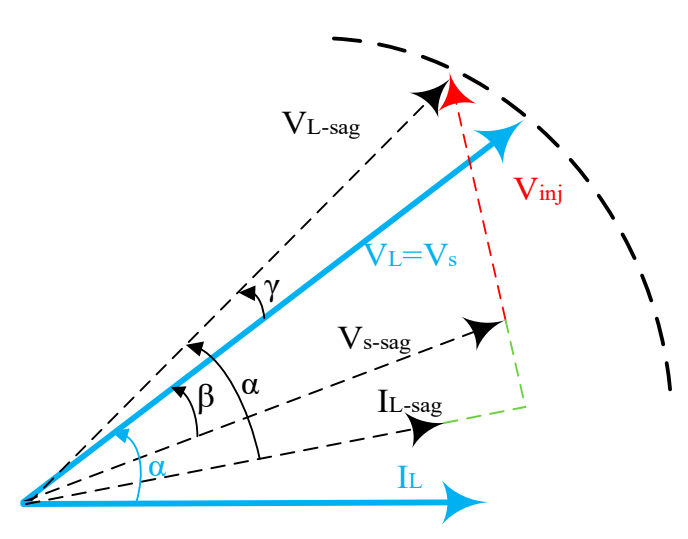

(c)

Figure 11. Cont. 


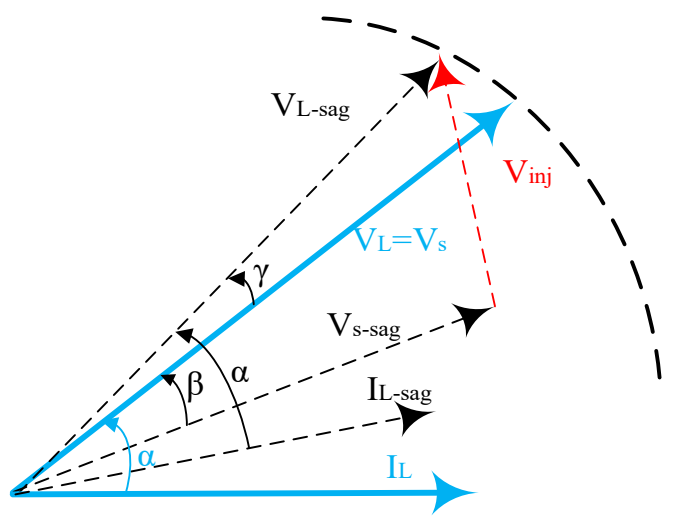

(d)

Figure 11. Phasor diagram of voltage compensation methods, (a) pre-sag, (b) in-phase, (c) energy-minimized (EM) for balanced sags, and (d) EM for imbalanced sags. Based on data from [129].

\subsubsection{Energy-Minimized Compensation Method}

In pre-sag and in-phase methods, the active power must be provided at the DC-link. However, in the energy-minimized (EM) method, there is no exchange of active power during the compensation stage. In other words, this method either inject to or absorb from the power supply to a greater extent for sag mitigation $[34,75,76,128]$. As the DVR does not exchange active power with power supply, the active power can be minimized. Not needing active power aside, the EM method has two downsides: the occurrence of phase jumps (so this method is not suitable for critical equipment that voltage magnitude is essential) and the magnitude of the injected voltage that may be higher [132]. What follows is the explanation of this compensation method in both balanced (Figure 11c) and unbalanced voltage sags (Figure 11d) [129].

\section{EM for Balanced Sag}

In Figure 11c, in which the EM compensation method is shown, the angle of $\gamma$ is the load voltage phase variation after sag [129]. As explained above, $P_{i n j}$ is zero to avert exchanging the active power. In turn, the injected voltage phasor is perpendicular to the load current phasor. Plus, this method is not suitable when it comes to under-voltage sags. One solution is using a thyristor-switched inductor connected in parallel with the DVR [76]. $\gamma$ is defined here to simplify the calculation of the injected voltage data as follows [129]:

$$
\begin{gathered}
V_{i n j}=\sqrt{2} \cdot \sqrt{\left(V_{L}\right)^{2}+\left(V_{s-s a g}\right)^{2}-2 \cdot V_{L} \cdot V_{s-s a g} \cdot \cos (\beta+\gamma)} \\
\angle V_{i n j, j}=\tan ^{-1}\left(\frac{V_{L} \cdot \sin (\alpha+\gamma)-V_{s-s a g} \cdot \sin (\alpha-\beta)}{V_{L} \cdot \cos (\alpha+\gamma)-V_{s-s a g} \cdot \cos (\alpha-\beta)}\right)
\end{gathered}
$$

\section{EM for Imbalanced Sag}

Figure 11d illustrates the EM compensation method for imbalanced voltage sags [129]. As can be seen, the injected voltage phasor is not perpendicular to the load current phasor. As a result, the exchanged active power in each phase is not zero. However, the total exchanged active power is zero. This means that if the active power in one phase is negative, the active power in the other two phases is positive. That way, the total exchanged active power is zero. The injected voltage data can be written as follows [129]:

$$
V_{i n j, j}=\sqrt{2} \cdot \sqrt{\left(V_{L}\right)^{2}+\left(V_{s-s a g, j}\right)^{2}-2 \cdot V_{L} \cdot V_{s-s a g, j} \cdot \cos \left(\beta_{j}+\gamma\right)}
$$




$$
\angle V_{\text {inj, } j}=\tan ^{-1}\left(\frac{V_{L} \cdot \sin (\alpha+\gamma)-V_{s-s a g, j} \cdot \sin \left(\alpha-\beta_{j}\right)}{V_{L} \cdot \cos (\alpha+\gamma)-V_{s-s a g, j} \cdot \cos \left(\alpha-\beta_{j}\right)}\right)
$$

Similar to the balanced voltage sag, the problem of deep voltage sags exists. The solution proposed in [76] can be applied to create the possibility of voltage sag compensation without active power. It is worth pointing out that the performance of the voltage compensation method can be affected by the type of load. A comparison of three voltage compensation methods is provided in Table 8 [126-129].

Table 8. Comparison of different voltage compensation methods. Based on data from [126-129].

\begin{tabular}{cccc}
\hline Criterion & Pre-Sag & In-Phase & EM \\
\hline $\begin{array}{c}\text { Magnitude/phase jump mitigation } \\
\text { Injected voltage magnitude }\end{array}$ & Magnitude/phase jump & Magnitude & Magnitude \\
Harmonic distortion & High & Low & Almost high \\
Balanced/imbalanced loads & Balanced/unbalanced & Balanced/unbalanced & - \\
Active/reactive power & Active/reactive & Active/reactive & Reactive (shallow sag), \\
active (deep sag) & Not completely \\
Voltage disturbance mitigation & Completely & Not completely & Linear \\
Suggested load & Non-linear, sensitive & Linear & Minimized \\
Need for energy storage & High & High & High \\
Need for DC-link & Medium & & Low
\end{tabular}

\subsection{Reference Generation and Modulation Stages}

The most commonly used method for generating reference voltage is Clarke and Park transformations (Figure 12) [69]. The description of this method is as follows. The three-phase supply voltage $\left(V_{S, a b c}\right)$ is transformed into the two-phase supply voltage $\left(V_{S, \alpha \beta}\right)$. The first transform does this ( $a b c / \alpha \beta$ transform). The $V_{S, \alpha \beta}$ is adjusted with the PLL, the output of which is the angle $(\theta)$. This angle is needed for the second transform $(\alpha \beta / d q$ transform). The output of this transform is $V_{S, d q}$. Next, with subtracting this $V_{S, d q}$ from the DC values of the reference voltage (here the DVR reference load voltage), $V_{L, d q}^{r e f}$ the reference injected voltage in the $d q$ reference frame, $V_{i n j, d q}^{r e f}$. Note that $V_{L, q}^{r e f}=0$. The following is the transformation of this reference value back to $\alpha \beta$ reference frame $(d q / \alpha \beta$ transform). The output is $V_{L, \alpha \beta}^{r e f}$ and then the transformation of the two-phase supply voltage back to the three-phase supply voltage, thereby providing the injected voltages' reference values for each phase. For each voltage compensation method, the calculation of $\theta$ varies. In the in-phase method, the PLL is locked to the supply voltage, thereby adjusting the system with the supply voltage. However, the PLL in the pre-sag method is maintained to the pre-sag value to modify $\theta$ with the pre-sag supply voltage. However, $\theta$ in the EM compensation method is measured by the PLL and this compensation method's equations as well.

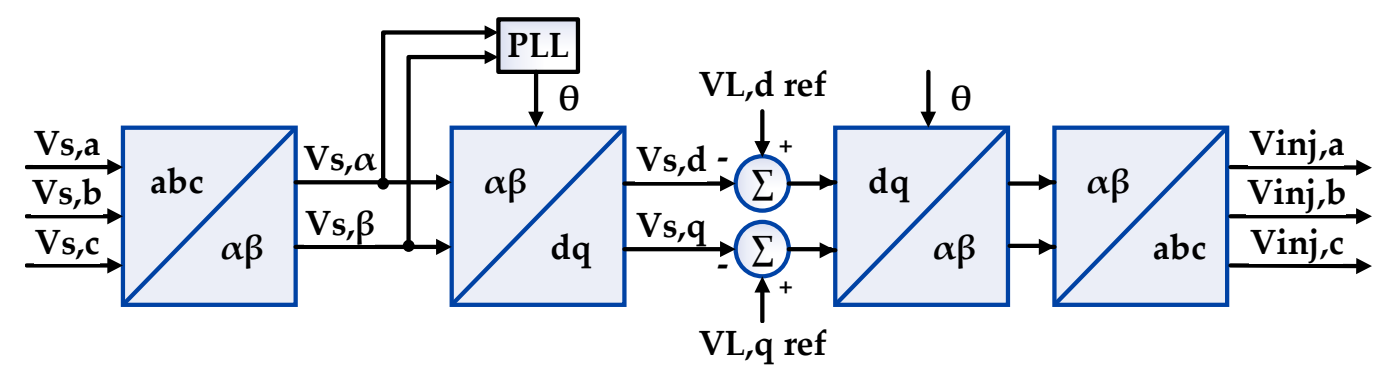

Figure 12. Voltage reference generation with Clark and Park transformations. Based on data from [69].

There are also other reference generation methods like Symmetric Component Estimation [133,134], Instantaneous Power Theory (PQR) [135,136], and Phasor Parameter Estimation [137]. After the reference voltages are generated, they are given to the pulse generation unit for creating pulses 
for the converter. To that end, the feed-forward controller, which is simple to implement and stable, serves the purpose. This method has the disadvantages of slow response and steady-state error. One solution is feedback or the hybrid of feedback and feed-forward controllers [138]. A comparison between feedback, feed-forward, and composite controllers is provided in Table 9 [138]. The calculated DVR voltage or load voltage in the feedback controller is affected by a voltage controller, like Proportional-Resonant (PR) [139], H infinity $\left(H_{\infty}\right)[140,141]$, Repetitive [67,142,143], Predictive [7,144,145], combined Feed-Forward and State Feedback [146], State Variable [147], Feedback Linearization [148], Sliding Mode (SMC) [149-152], and Metaheuristic Algorithms like Fuzzy Logic (FLC) [95,153,154], Hybrid Genetic Algorithm (GA) and FLC (GA FCL) [155], Cuckoo Search (CS) [156], Chaotic Accelerated PSO (CAPSO) [157], Artificial Neural Network (ANN) [46,158,159], to name just a few.

Table 9. Comparison between Feedback, Feed-forward, and Composite controllers. Based on data from [138].

\begin{tabular}{cccc}
\hline Criterion & Feed Forward & Feedback & Composite \\
\hline Complexity & Simple & Complex & - \\
Injected voltage control & Hard & Easy & - \\
Harmonic distortion & Low & High & Supply (feed-forward) and load \\
Voltage side & Supply & Load & (feedback) \\
Steady-state error & High & Low & Low \\
Stability & High & Low & High (if double-loop is considered \\
Response speed & Fast & Slow & for the feedback control) \\
Transient overshoot control & Hard & Easy & Fast \\
Asymmetrical faults mitigation & Low & High & - \\
\hline
\end{tabular}

After the reference voltage is generated, they are used for the generation of switching pulses for the converter. There are several methods for this purpose like Sinusoidal PWM (SPWM) and Space Vector PWM (SVPWM) [160-164], Selective Harmonic Eliminated PWM (SHE PWM) [164,165], Fundamental Frequency [113,166], Hysteresis and dead-band [167-169], Level-Shifted Carrier PWM (LSPWM) and Single-Carrier PWM (SCPWM) [170].

\section{DVR: Modified Configurations}

The conventional DVR configurations have some disadvantages, like being costly or the need for energy storage when there are prolonged voltage disturbances. To address this, many improved DVR configurations have been presented. The most important ones are described below.

After fault detection, the chances are that the fault current experienced in the DVR cause damage in the DVR. One idea is to protect the DVR from the fault current. Although many bypass switches can do this, a better solution is to combine the DVR with Fault Current Limiter or Controller (FCC) (Figure 13a) [78,171-174]. The FCC DVR is more than capable of limiting the fault current and averts any damage to the DVR. The FCC DVR has two operation modes of voltage disturbance compensation and short-circuits current limitations. Another modified DVR configuration is an Interline DVR (IDVR) which is a cost-effective approach since it is comprised of several DVR systems on different lines with a common DC-link that results in a significant reduction in the DC-link's size, as opposed to the idea of using several DVRs and considering energy storage for every single DVR [175]. It also enables the active power exchange between two or more DVRs. If one of the DVRs mitigates the sag and provides real power from the sharing DC-link, the rest of the DVRs are to supply it to keep its voltage above a specific threshold value [176]. However, some optimized and modified IDVRs have been presented [175,177-181]. In an IDVR with two different feeders shown in Figure 13b, the active power required for voltage is provided by the DC-link capacitor or by the nearest feeder. 
One idea is to connect renewable energy sources and batteries across the common DC-link to share the required active power when the nearest feeder cannot compensate the sag, or there are two sags on both feeders at the same time. Transformer-less DVR (TDVR) is another DVR configuration $[113,144,182,183]$. TDVR topology, like its name suggests, has no injection transformers (see Figure 13c). TDVR has two operation modes of self-charging and voltage disturbance compensation. Under normal and healthy conditions, TDVR is in the self-charging mode. Once a voltage disturbance occurs, the TDVR switches to the voltage disturbance compensation mode. There is no transformer saturation and inrush current issues in TDVR, therefore, the cost, volume, and weight are reduced. However, TDVR topology is not appropriate for HV applications. Additionally, the TDVR with three full-bridge inverters is illustrated in Figure 13d [73] (see Figure 8c) for the transformer connected DVR with three full-bridge inverters. It should be pointed out that the injection transformer can be removed, provided the DVR has the energy storage or the DC-link. Moreover, the injection transformer is required for isolation if the DC-link is provided from the supply.

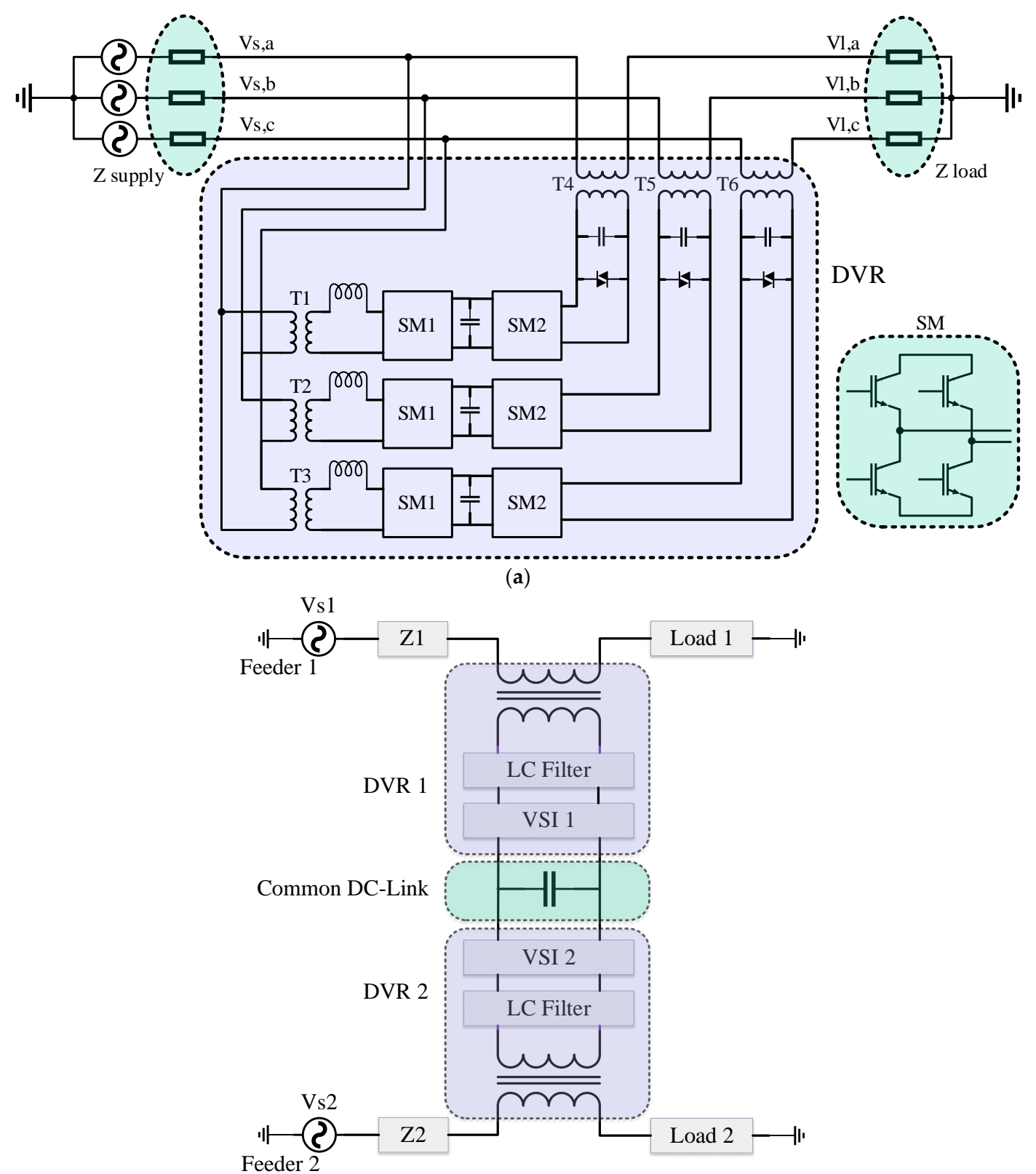

(b)

Figure 13. Cont. 


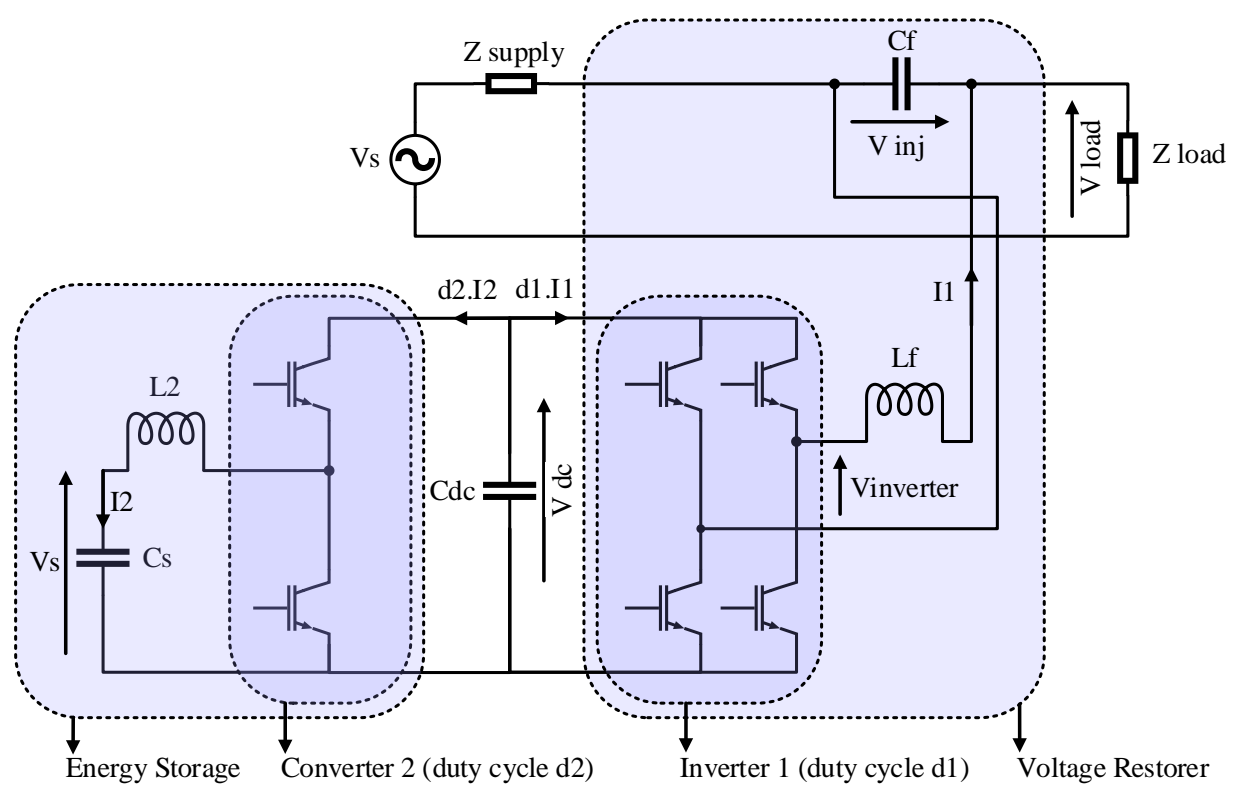

(c)

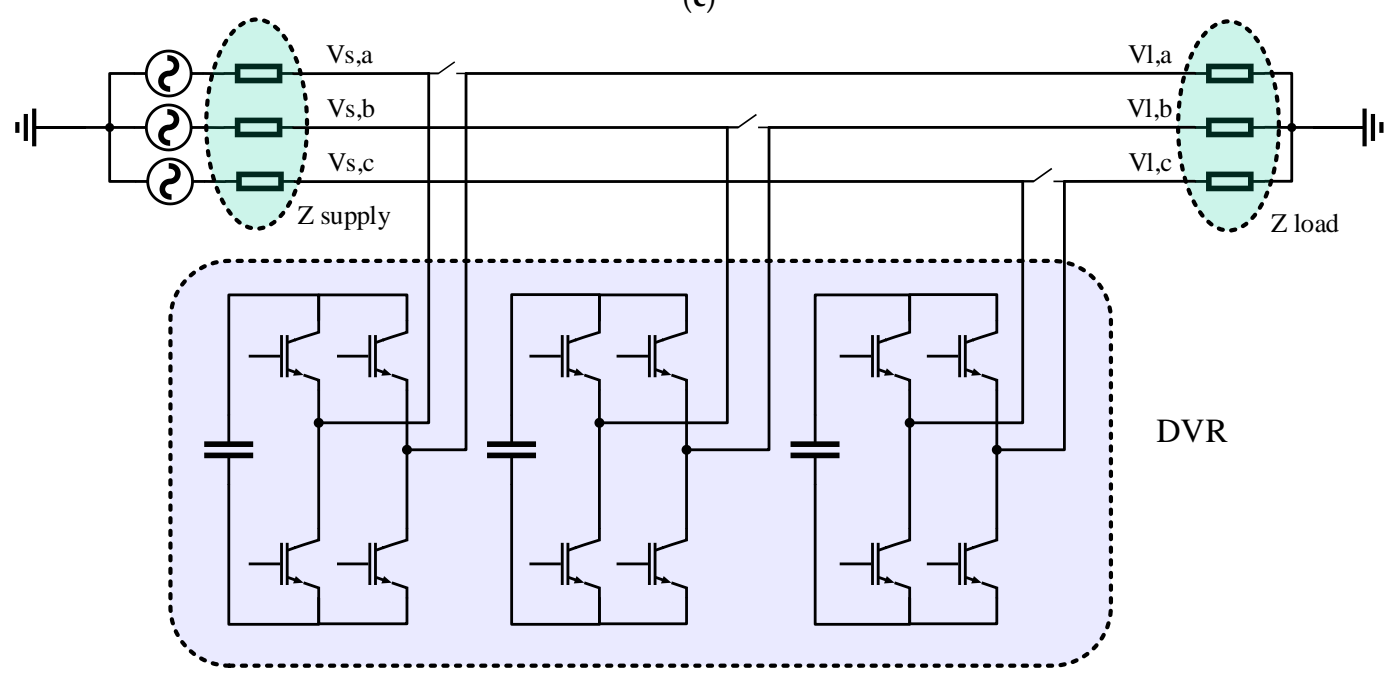

(d)

Figure 13. Modified DVR configurations: (a) Fault Current Limiter/Controller DVR (FCC DVR), (b) Interline DVR (IDVR) with two independent feeders, (c) Transformer-less DVR (TDVR), and (d) Transformer-less DVR (TDVR) with three full-bridge inverters. Based on data from [73,76,78,113,144,171-183].

\section{Distributed Generation Integration with DVR}

The DVR only works if a voltage disturbance is found. However, in healthy conditions, the DVR exists in standby mode. In conventional DVRs, high capacity DC storage units like UCAPs, Batteries, FESS, or SMES. Over the years, however, renewable energy sources have become popular, and researchers are leaning toward using such sources [184], especially their integration with FACTS [185]. A great idea is the integration of Photovoltaic (PV) and DVR (PV DVR) in a way that, under normal conditions, the PV DVR injects the power of PV into the supply, and when a voltage disturbance happens, the PV is employed to mitigate the voltage disturbance. In fact, in healthy conditions, the PV DVR serves as online UPS for the injection of the PV power to the load. Although the PV DVR provides a series voltage to the supply, the injected voltage data must be controlled to keep the magnitude of load voltage unchanged [186-188]. Note that the injection of PV power into the supply through the DVR may not be a good idea for the increase in the inverter's ratings. In [189], a continuous and online control strategy has been proposed for DVR used in residential networks with PV systems 
to provide voltage quality improvement and maximize PV power injection. Using a Fuel Cell in DVR (FC DVR) as an energy source is another solution [120]. However, it may not be a cost-effective approach. The advantages and disadvantages of modified DVR configurations, including IDVR, TDVR, DVR based on direct AC/AC converters, and PV DVR are provided in Table 10 [175-183,186-188].

Table 10. Modified DVR topologies, along with their advantages and disadvantages. Based on data from [175-183,186-188].

\begin{tabular}{|c|c|c|}
\hline Modified Topology & Advantages & Disadvantages \\
\hline IDVR & $\begin{array}{l}\text { Cost-effective solution (sharing } \\
\text { standard energy storage), reduced } \\
\text { the size of DC-link capacity, long } \\
\text { and deep sags mitigation, easy to } \\
\text { implement, power flow control }\end{array}$ & $\begin{array}{l}\text { Real power is sensitive to the load } \\
\text { power flow, if the nearest feeder } \\
\text { cannot compensate the sag or there } \\
\text { are two sags on both feeders at the } \\
\text { same time, distributed generations } \\
\text { or batteries must be lined across } \\
\text { the common DC-link for sharing } \\
\text { of the required active power }\end{array}$ \\
\hline TDVR & $\begin{array}{l}\text { No transformer saturation and } \\
\text { inrush current issues, lower cost, } \\
\text { no bulky transformer }\end{array}$ & $\begin{array}{l}\text { Not suitable for HV applications, } \\
\text { difficult converter implementation, } \\
\text { more components }\end{array}$ \\
\hline Direct $\mathrm{AC} / \mathrm{AC}$ converters & $\begin{array}{c}\text { Lower cost, less installation space, } \\
\text { extended sag mitigation, reduced } \\
\text { size and weight (no DC-link or } \\
\text { energy storage unit) }\end{array}$ & $\begin{array}{l}\text { Number of switches are high, fails } \\
\text { to mitigate deep sags }\end{array}$ \\
\hline PV DVR & $\begin{array}{l}\text { Zero-emission, no need for } \\
\text { high-capacity DC storage, } \\
\text { no greenhouse gases to be emitted } \\
\text { after installation, return on } \\
\text { investment instead of paying } \\
\text { electricity bills }\end{array}$ & $\begin{array}{l}\text { High initial material and } \\
\text { installation costs, no solar power } \\
\text { at night, lower solar power on } \\
\text { cloudy days, lower solar power in } \\
\text { the winter months, producing DC } \\
\text { and need for DC/AC converters }\end{array}$ \\
\hline
\end{tabular}

The integration of DGs and DVR has become popular [190-192]. This is even important for Low-Voltage Ride-Through (LVRT) capabilities in wind turbines. Having this capability sets the stage for maintaining wind turbines, particularly DFIG wind turbines, connected to the supply during sags [138,193-198]. The optimal scheduling of a microgrid including thermal and electrical loads, DGs like PV solar and wind turbine, Combined Heat and Power (CHP), traditional energy sources like boiler and microturbine, energy storage systems, and DVR has been studied in [199]. In grid-connected PV systems, voltage sags can be caused by Partial Shading Conditions (PSC) due to reasons like passing clouds, nearby buildings, and growing trees. In this case, Maximum Power Point Tracking (MPPT) methods are used to extract the maximum PV power $[200,201]$ and as well as that the DVR is connected in series with PCC to compensate and mitigate voltage sags due to PSCs [18,192]. An in-depth review of different control strategies and algorithms for the integration of DGs with distributed FACTS like DVR and DSTATCOM has been provided in [202].

\section{Conclusions}

In this paper, a comprehensive review of various types of DVR systems, and its practical difficulties and future scope for research trends are presented. Studies that have reviewed the DVR are many, but different power quality issues, the DVR principle, and operation modes, along with the DVR components, the DVR topologies based on energy storage, or the lack thereof are discussed in this paper. In particular, the DVR topologies based on power converters, and the DVR topologies based on control units and their different stages for each operation mode, are all explained based on the state-of-the-art in literature in detail. Various modified and improved DVR configurations, along with the integration of renewable energy sources, are also presented. This review paves the way for singling 
out the best, most reasonably-priced, and high-performance DVR topology as per the wants and needs of researchers and scientists whose research interests are within this field of research for futuristic tends.

The scopes of the art for future research are many. Some important aspects are recommended, but not limited to:

- Voltage sags were just considered as voltage disturbances in many studies and the DVR was used to mitigate them. Voltage swells must be included for better analysis of the DVR. Additionally, voltage spikes were neglected, as they occur in the initial and final stages of voltage disturbances. Eliminating or decreasing them causes a harmonic reduction.

- Using modified power converters in DVR is another idea. That way, we can improve the performance of DVR in terms of cost, efficiency, reliability, LVRT capability, deep/long voltage sags/swells compensation simultaneously, harmonic, etc.

- The method used in the detection stage can be modified in a way that the detection process becomes highly reliable, particularly when it comes to deep/long voltage sags/swells.

- Hybrid metaheuristic algorithms to find the best optimal solutions.

- Modified DVR configurations can improve DVR efficiency. However, they have more elements. Coming up with a solution to reduce passive elements will cut down on the cost.

- The integration of DGs and DVR has become popular. The main focus of studies, however, has been on the integration of DVR and PV systems per se or wind turbines. For future works, the integration of DVR and smart grids and microgrids should be considered.

Author Contributions: A.M. and S.P. contributed equally to the final presentation of this research work as a full article in the current form. All authors have read and agreed to the published version of the manuscript.

Funding: This research received no external funding.

Conflicts of Interest: The authors declare no conflict of interest.

\section{Nomenclature}

$\begin{array}{ll}\text { AC } & \text { Alternating Current } \\ \text { ANN } & \text { Artificial Neural Network } \\ \text { APF } & \text { Active Power Filter } \\ \text { BESS } & \text { Battery Energy Storage System } \\ \text { CAPSO } & \text { Chaotic Accelerated PSO } \\ \text { CHB MLI } & \text { Cascaded H-Bridge Multilevel Inverter } \\ \text { CHP } & \text { Combined Heat and Power } \\ \text { CPD } & \text { Custom Power Device } \\ \text { CS } & \text { Cuckoo Search } \\ \text { DC MLI } & \text { Diode-Clamped Multilevel Inverter } \\ \text { DFIG } & \text { Doubly-Fed Induction Generator } \\ \text { DFT } & \text { Discrete Fourier Transform } \\ \text { DG } & \text { Distributed Generations } \\ \text { DSTATCOM } & \text { Distribution Static Synchronous Compensator } \\ \text { DVR } & \text { Dynamic Voltage Restorer } \\ \text { EM } & \text { Energy-minimized } \\ \text { FACTS } & \text { Flexible AC Transmission Systems } \\ \text { FC } & \text { Fuel Cell } \\ \text { FC DVR } & \text { Fuel Cell Dynamic Voltage Restorer } \\ \text { FC MLI } & \text { Flying Capacitor Multilevel Inverter } \\ \text { FCC } & \text { Fault Current Limiter or Controller } \\ \text { FCC DVR } & \text { Fault Current Controller and Dynamic Voltage Restorer } \\ \end{array}$


FCL Fuzzy Logic controller

FESS Flywheel Energy Storage System

FT Fourier Transform

GA Genetic Algorithm

GA FCL Genetic Algorithm Fuzzy Logic Controller

HV High Voltage

IDVR Interline Dynamic Voltage Restorer

IEC International Electrotechnical Commission

IEEE Institute of Electrical and Electronics Engineers

IPFC Interline Power Flow Controller

KF Kalman Filter

LSPWM Level-Shifted Carrier Pulse Width Modulation

LV Low Voltage

LVTR Low-Voltage Ride-Through

MLI Multilevel Inverter

MPPT Maximum Power Point Tracking

MV Medium Voltage

NPC MLI Neutral-Point Clamped Multilevel Inverter

PCC Point of Common Coupling

PLL Phase-Locked Loop

PR Proportional-Resonant

PSC Partial Shading Conditions

PSO Particle Swarm Optimization

PV Photovoltaic

PV DVR Photovoltaic and DVR

PWM Pulse Width Modulation

RMS Root Mean Square

SA Surge Arrester

SCL Static Current Limiter

SCPWM Single-Carrier Pulse Width Modulation

SHE PWM Selective Harmonic Eliminated Pulse Width Modulation

SMC Sliding Mode control

SMES Superconducting Magnetic Energy Storage

SPWM Sinusoidal Pulse Width Modulation

SRF Synchronously Rotating Frame

SSCB Solid-state Circuit Breaker

SSSC Static Synchronous Series Compensator

SSTS Solid-state Transfer Switch

STATCOM Static Synchronous Compensator

SVC Static VAR Compensator

SVPWM Space Vector Pulse Width Modulation

TDVR Transformer-less DVR

TVSS Transient Voltage Surge Suppressor

UCAP Ultracapacitor

UPFC Unified Power Flow Controller

UPQC Unified Power Quality Conditioner

UPS Uninterruptible Power Supply

VSI Voltage Source Inverter

WFFT Windowed Fast Fourier Transform

WT Wavelet Transform

ZSI Impedance-source Inverter 


\section{References}

1. Arrillaga, J.; Watson, N.R.; Chen, S. Power System Quality Assessment; Wiley: Hoboken, NJ, USA, 2000.

2. Bollen, M.H.J. Understanding Power Quality Problems: Voltage Sags and Interruptions; Wiley-IEEE Press: Piscataway, NJ, USA, 2000.

3. Dugan, R.C.; McGranaghan, M.F.; Santoso, S.; Beaty, H.W. Electrical Power Systems Quality, 3rd ed.; McGraw Hill: New York, NY, USA, 2012.

4. $\quad$ Baggini, A. Handbook of Power Quality; Wiley: Hoboken, NJ, USA, 2008.

5. Sankaran, C. Power Quality; CRC Press: Boca Raton, FL, USA, 2002.

6. Kusko, A.; Thompson, M.T. Power Quality in Electrical Systems; McGraw Hill: New York, NY, USA, 2007.

7. Moreno-Muñoz, A. (Ed.) Power Quality: Mitigation Technologies in a Distributed Environment; Springer: London, UK, 2007.

8. Ghosh, A.; Ledwich, G. Power Quality Enhancement Using Custom Power Devices; Springer: Berlin/Heidelberg, Germany, 2002.

9. Brumsickle, W.E.; Schneider, R.S.; Luckjiff, G.A.; Divan, D.M.; McGranaghan, M.F. Dynamic sag correctors: Cost-effective industrial power line conditioning. IEEE Trans. Ind. Appl. 2001, 37, 212-217. [CrossRef]

10. McGranaghan, M.F.; Mueller, D.R.; Samotyj, M.J. Voltage sags in industrial systems. IEEE Trans. Ind. Appl. 1993, 29, 397-403. [CrossRef]

11. Ghosh, A.; Ledwich, G. Compensation of distribution system voltage using DVR. IEEE Trans. Power Deliv. 2002, 17, 1030-1036. [CrossRef]

12. Woodley, N.H.; Morgan, L.; Sundaram, A. Experience with an inverter-based dynamic voltage restorer. IEEE Trans. Power Deliv. 1999, 14, 1181-1186. [CrossRef]

13. Padiyar, K.R. Facts Controllers in Power Transmission and Distribution; New Age International: New Delhi, India, 2008.

14. Babu, B.P.; Indragandhi, V. A Review on Dynamic Voltage Restorer in power systems concerned to the issues of Power Quality. IOP Conf. Ser. Mater. Sci. Eng. 2019, 623, 012015. [CrossRef]

15. Remya, V.K.; Parthiban, P.; Ansal, V.; Babu, B.C. Dynamic voltage restorer (DVR)—A review. J. Green Eng. 2018, 8, 519-572. [CrossRef]

16. Praveen, J.; Muni, B.P.; Venkateshwarlu, S.; Makthal, H.V. Review of dynamic voltage restorer for power quality Improvement. In Proceedings of the 30th Annual Conference of IEEE Industrial Electronics Society, Busan, South Korea, 2-6 November 2004; Volume 1, pp. 749-754. [CrossRef]

17. Hossain, E.; Tür, M.R.; Padmanaban, S.; Ay, S.; Khan, I. Analysis and mitigation of power quality issues in distributed generation systems using custom power devices. IEEE Access 2018, 6, 16816-16833. [CrossRef]

18. Moghassemi, A.; Hosseini, M.; Olamaei, J. Power quality improvement of grid-connected photovoltaic systems using Trans-z-source inverter under partial shading condition. Iran. J. Sci. Technol.-Trans. Electr. Eng. 2020. [CrossRef]

19. Stump, M.D.; Keane, G.J.; Leong, F.K. The role of custom power products in enhancing power quality at industrial facilities. In Proceedings of the EMPD'98. 1998 International Conference on Energy Management and Power Delivery (Cat. No. 98EX137), Singapore, 3-5 March 1998; Volume 2, pp. 507-517. [CrossRef]

20. IEEE 519. Recommended Practice and Requirements for Harmonic Control in Electric Power Systems; IEEE: Piscataway, NJ, USA, 2014. [CrossRef]

21. IEC 61000-3-2. Electromagnetic Compatibility (EMC)—Part 3-2: Limits_Limits for Harmonic Current Emissions (Equipment Input Current $\leq 16$ A Per Phase); IEC: Geneva, Switzerland, 2018.

22. IEC TS 61000-3-4. Electromagnetic Compatibility (EMC)—Part 3-4: Limits_Limitation of Emission of Harmonic Currents in Low-Voltage Power Supply Systems (Equipment with Rated Current Greater than 16 A); IEC: Geneva, Switzerland, 1998.

23. IEEE 141. Recommended Practice for Electric Power Distribution for Industrial Plants; IEEE: Piscataway, NJ, USA, 1986. [CrossRef]

24. IEEE 1159. Recommended Practice for Monitoring Electric Power Quality; IEEE: Piscataway, NJ, USA, 2019. [CrossRef]

25. IEEE 1250. Guide for Identifying and Improving Voltage Quality in Power Systems; IEEE: Piscataway, NJ, USA, 2018. [CrossRef]

26. IEEE P1564. Guide for Voltage Sag Indices; IEEE: Piscataway, NJ, USA, 2014. 
27. IEC 61000-4-15. Electromagnetic Compatibility (EMC)_Part 4-15: Testing and Measurement Techniques_Flickermeter_Functional and Design Specifications; IEC: Geneva, Switzerland, 2017.

28. IEEE P1409. Draft Guide for the Application of Power Electronics for Power Quality Improvement on Distribution Systems Rated 1 kV Through 38 kV; IEEE: Piscataway, NJ, USA, 2012.

29. IEEE P1547. Approved Draft Standard Conformance Test Procedures for Equipment Interconnecting Distributed Energy Resources with Electric Power Systems and Associated Interfaces; IEEE: Piscataway, NJ, USA, 2020.

30. Pillay, P.; Manyage, M. Definitions of voltage unbalance. IEEE Power Eng. Rev. 2001, 21, 50-51. [CrossRef]

31. Golkar, M.A. Power quality in electric networks: Monitoring and standards. Renew. Energ. Power Qual. J. REPQJ 2002, 1, 291-294. [CrossRef]

32. El-Gammal, M.A.; Abou-Ghazala, A.Y.; ElShennawy, T.I. Dynamic voltage restorer (DVR) for voltage sag mitigation. Int. J. Electr. Eng. Inform. 2011, 3, 1-11. [CrossRef]

33. Boonchiam, P.; Mitholananthan, N. Understanding of dynamic voltage restorers through MATLAB simulation. Thammasat Int. J. Sci. Technol. 2006, 11, 1-6.

34. Ho, C.N.M.; Chung, H.S.; Au, K.T. Design and implementation of a fast dynamic control scheme for capacitor-supported dynamic voltage restorers. IEEE Trans. Power Electron. 2008, 23, 237-251. [CrossRef]

35. Perera, K.; Salomonsson, D.; Atputharajah, A.; Alahakoon, S. Automated control technique for a single phase dynamic voltage restorer. In Proceedings of the 2006 International Conference on Information and Automation, Shandong, China, 15-17 December 2006; pp. 63-68. [CrossRef]

36. Li, Y.W.; Loh, P.C.; Blaabjerg, F.; Vilathgamuwa, D.M. Investigation and improvement of transient response of DVR at medium voltage level. IEEE Trans. Ind. Appl. 2007, 43, 1309-1319. [CrossRef]

37. Ramachandaramurthy, V.K.; Fitzer, C.; Arulampalam, A.; Zhan, C.; Barnes, M.; Jenkins, N. Control of a battery supported dynamic voltage restorer. IEE Proc.-Gener. Transm. Distrib. 2002, 149, 533-542. [CrossRef]

38. Silva, S.M.; Filho, B.J.C. Component-minimized voltage sag compensators. In Conference Record of the 2002 IEEE Industry Applications Conference, Proceedings of the 37th IAS Annual Meeting (Cat. No.02CH37344), Pittsburgh, PA, USA, 13-18 October 2002; IEEE: New York, NY, USA, 2002; Volume 2, pp. 883-889. [CrossRef]

39. Buxton, R. Protection from voltage dips with the dynamic voltage restorer. In Proceedings of the IEE Half Day Colloquium on Dynamic voltage Restorers-Replacing Those Missing Cycles (Digest No. 1998/189), Glasgow, UK, 11 February 1998. [CrossRef]

40. Moghassemi, A.; Rostampoor, K. The use of new control technique in DVR as a series compensator to protect sensitive loads against voltage disturbances. In Proceedings of the 1st Conference on Electrical and Electronic Engineering North West of Iran, Tabriz, Iran, 26-27 July 2014; pp. 76-81.

41. Al Hosani, K.; Nguyen, T.H.; Al Sayari, N. An improved control strategy of 3P4W DVR systems under unbalanced and distorted voltage conditions. Int. J. Electr. Power Energy Syst. 2018, 98, 233-242. [CrossRef]

42. Ramachandaramurthy, V.K.; Arulampalam, A.; Fitzer, C.; Zhan, C.; Barnes, M.; Jenkins, N. Supervisory control of dynamic voltage restorers. IEE Proc.-Gener. Transm. Distrib. 2004, 151, 509-516. [CrossRef]

43. Fitzer, C.; Arulampalam, A.; Barnes, M.; Zurowski, R. Mitigation of saturation in dynamic voltage restorer connection transformers. IEEE Trans. Power Electron. 2002, 17, 1058-1066. [CrossRef]

44. Jothibasu, S.; Mishra, M.K. A control scheme for storageless DVR based on characterization of voltage sags. IEEE Trans. Power Deliv. 2014, 29, 2261-2269. [CrossRef]

45. Somayajula, D.; Crow, M.L. An ultracapacitor integrated power conditioner for intermittency smoothing and improving power quality of distribution grid. IEEE Trans. Sustain. Energy 2014, 5, 1145-1155. [CrossRef]

46. Banaei, M.R.; Hosseini, S.H.; Khanmohamadi, S.; Gharehpetian, G.B. Verification of a new energy control strategy for dynamic voltage restorer by simulation. Simul. Model. Pract. Theory 2006, 14, 112-125. [CrossRef]

47. Seng, L.Y. Algorithm for designing the size of energy storage in dynamic voltage restorer. In Proceedings of the First International Conference on Industrial and Information Systems, Peradeniya, Sri Lanka, 8-11 August 2006; pp. 46-51. [CrossRef]

48. Vilathgamuwa, D.M.; Wijekoon, H.M. Mitigating zero sequence effects in dynamic voltage restorers. In Proceedings of the 2007 IEEE Power Electronics Specialists Conference, Orlando, FL, USA, 17-21 June 2007; pp. 3079-3085. [CrossRef]

49. Zhan, C.; Ramachandaramurthy, V.K.; Arulampalam, A.; Fitzer, C.; Kromlidis, S.; Bames, M.; Jenkins, N. Dynamic voltage restorer based on voltage-space-vector PWM control. IEEE Trans. Ind. Appl. 2001, 37, 1855-1863. [CrossRef] 
50. Kim, H.; Kim, J.H.; Sul, S.K. A design consideration of output filters for dynamic voltage restorers. In Proceedings of the 2004 IEEE 35th Annual Power Electronics Specialists Conference (IEEE Cat. No. 04CH37551), Aachen, Germany, 20-25 June 2004; Volume 6, pp. 4268-4272. [CrossRef]

51. Choi, S.S.; Li, B.H.; Vilathgamuwa, D.M. A comparative study of inverter-and line-side filtering schemes in the dynamic voltage restorer. In Proceedings of the 2000 IEEE Power Engineering Society Winter Meeting. Conference Proceedings (Cat. No. 00CH37077), Singapore, 23-27 January 2000; Volume 4, pp. 2967-2972. [CrossRef]

52. Choi, S.S.; Li, B.H.; Vilathgamuwa, D.M. Design and analysis of the inverter-side filter used in the dynamic voltage restorer. IEEE Trans. Power Deliv. 2002, 17, 857-864. [CrossRef]

53. Omar, R.; Rahim, N.A.; Sulaiman, M. Dynamic voltage restorer application for power quality improvement in electrical distribution system: An overview. Aust. J. Basic Appl. Sci. 2011, 5, 379-396.

54. Nielsen, J.G.; Blaabjerg, F. A detailed comparison of system topologies for dynamic voltage restorers. IEEE Trans. Ind. Appl. 2005, 41, 1272-1280. [CrossRef]

55. Vilathgamuwa, D.M.; Gajanayake, C.J.; Loh, P.C.; Li, Y.W. Voltage sag compensation with Z-source inverter based dynamic voltage restorer. In Proceedings of the Conference Record of the 2006 IEEE Industry Applications Conference Forty-First IAS Annual Meeting, Tampa, FL, USA, 8-12 October 2006; Volume 5, pp. 2242-2248. [CrossRef]

56. Balamurugan, M.; Sivakumaran, T.S.; Aishwariya, M. Voltage sag/swell compensation using Z-source inverter DVR based on FUZZY controller. In Proceedings of the 2013 IEEE International Conference ON Emerging Trends in Computing, Communication and Nanotechnology (ICECCN), Tirunelveli, India, 25-26 March 2013; pp. 453-648. [CrossRef]

57. Banaei, M.R.; Dehghanzadeh, A.R. DVR based cascaded multilevel Z-source inverter. In Proceedings of the 2010 IEEE International Conference on Power and Energy, Manama, Bahrain, 18-22 December 2010; pp. 51-56. [CrossRef]

58. Torabzad, S.; Babaei, E.; Kalantari, M. Z-source inverter based dynamic voltage restorer. In Proceedings of the 2010 1st Power Electronic \& Drive Systems \& Technologies Conference (PEDSTC), Tehran, Iran, 17-18 February 2010; pp. 406-411. [CrossRef]

59. Fernandes, D.A.; Naidu, S.R.; Lima, A.M.N. A four leg voltage source converter based dynamic voltage restorer. In Proceedings of the 2008 IEEE Power Electronics Specialists Conference, Rhodes, Greece, 15-19 June 2008; pp. 3760-3766. [CrossRef]

60. Fernandes, D.A.; Naidu, S.R. A novel PWM scheme for the 4-leg voltage source converter and its use in dynamic voltage restoration. In Proceedings of the 2007 IEEE Power Engineering Society General Meeting, Tampa, FL, USA, 24-28 June 2007; pp. 1-5. [CrossRef]

61. Naidu, S.R.; Fernandes, D.A. Generation of unbalanced 3-phase voltages for dynamic voltage restoration using the 4-leg voltage source converter. In Proceedings of the 2007 IEEE Power Electronics Specialists Conference, Orlando, FL, USA, 17-21 June 2007; pp. 1195-1200. [CrossRef]

62. Tashackori, A.; Hosseini, S.H.; Sabahi, M.; Nouri, T. A three-phase four-leg DVR using three dimensional space vector modulation. In Proceedings of the 2013 21st Iranian Conference on Electrical Engineering (ICEE), Mashhad, Iran, 14-16 May 2013; pp. 1-5. [CrossRef]

63. Boonchiam, P.; Mithulananthan, N. Diode-clamped multilevel voltage source converter based on medium voltage DVR. Int. J. Electr. Power Energy Syst. Eng. 2008, 1, 62-67.

64. Meyer, C.; Romaus, C.; DeDoncker, R.W. Five level neutral-point clamped inverter for a dynamic voltage restorer. In Proceedings of the 2005 European Conference on Power Electronics and Applications, Dresden, Germany, 11-14 September 2005; pp. P.1-P.9. [CrossRef]

65. Barros, J.D.; Silva, J.F. Multilevel optimal predictive dynamic voltage restorer. IEEE Trans. Ind. Electron. 2009, 57, 2747-2760. [CrossRef]

66. Bhumkittipich, K.; Chankhamrian, W.; Mithulananthan, N. Application of three-level diode-clamped converter on $10 \mathrm{~kW}$ distribution voltage restorer. Energy Procedia 2013, 34, 116-129. [CrossRef]

67. Rodriguez, J.; Franquelo, L.G.; Kouro, S.; Leon, J.I.; Portillo, R.C.; Prats, M.A.M.; Perez, M.A. Multilevel converters: An enabling technology for high-power applications. Proc. IEEE 2009, 97, 1786-1817. [CrossRef]

68. Sadigh, A.K.; Hosseini, S.H.; Barakati, S.M.; Gharehpetian, G. Flying capacitor multicell converter based dynamic voltage restorer. In Proceedings of the 41st North American Power Symposium, Starkville, MS, USA, 4-6 October 2009; pp. 1-6. [CrossRef] 
69. Roncero-Sanchez, P.; Acha, E. Dynamic voltage restorer based on flying capacitor multilevel converters operated by repetitive control. IEEE Trans. Power Deliv. 2009, 24, 951-960. [CrossRef]

70. Wang, B.; Illindala, M. Operation and control of a dynamic voltage restorer using transformer coupled H-bridge converters. IEEE Trans. Power Electron. 2006, 21, 1053-1061. [CrossRef]

71. Massoud, A.M.; Ahmed, S.; Enjeti, P.N.; Williams, B.W. Evaluation of a multilevel cascaded-type dynamic voltage restorer employing discontinuous space vector modulation. IEEE Trans. Ind. Electron. 2010, 57, 2398-2410. [CrossRef]

72. Galeshi, S.; Iman-Eini, H. A dynamic voltage restorer using multilevel cascaded inverter and capacitors as energy sources. In Proceedings of the 2012 3rd Power Electronics and Drive Systems Technology (PEDSTC), Tehran, Iran, 15-16 February 2012; pp. 296-301. [CrossRef]

73. Wang, S.; Tang, G.; Yu, K.; Zheng, J. Modeling and control of a novel transformer-less dynamic voltage restorer based on H-bridge cascaded multilevel inverter. In Proceedings of the 2006 International Conference on Power System Technology, Chongqing, China, 22-26 October 2006; pp. 1-9. [CrossRef]

74. Loh, P.C.; Vilathgamuwa, D.M.; Tang, S.K.; Long, H.L. Multilevel dynamic voltage restorer. In Proceedings of the 2004 International Conference on Power System Technology, PowerCon, Singapore, 21-24 November 2004; Volume 2, pp. 1673-1678. [CrossRef]

75. Al-Hadidi, H.K.; Gole, A.M.; Jacobson, D.A. Minimum power operation of cascade inverter based dynamic voltage restorer. IEEE Trans. Power Deliv. 2008, 23, 889-898. [CrossRef]

76. Al-Hadidi, H.K.; Gole, A.M.; Jacobson, D.A. A novel configuration for a cascade inverter-based dynamic voltage restorer with reduced energy storage requirements. IEEE Trans. Power Deliv. 2008, 23, 881-888. [CrossRef]

77. Galeshi, S.; Iman-Eini, H. Dynamic voltage restorer employing multilevel cascaded H-bridge inverter. Iet Power Electron. 2016, 9, 2196-2204. [CrossRef]

78. Jiang, F.; Tu, C.; Shuai, Z.; Cheng, M.; Lan, Z.; Xiao, F. Multilevel cascaded-type dynamic voltage restorer with fault current-limiting function. IEEE Trans. Power Deliv. 2015, 31, 1261-1269. [CrossRef]

79. Pires, V.F.; Guerreiro, M.; Silva, J.F. Dynamic voltage restorer using a multilevel converter with a novel cell structure. In Proceedings of the 2011 IEEE EUROCON-International Conference on Computer as a Tool, Lisbon, Portugal, 27-29 April 2011; pp. 1-4. [CrossRef]

80. Ajami, A.; Armaghan, M. A new concept of multilevel DVR based on mixed multi-cell cascaded topology. In Proceedings of the 2010 International Conference on Mechanical and Electrical Technology, Singapore, 10-12 September 2010; pp. 398-402. [CrossRef]

81. Sadigh, A.K.; Babaei, E.; Hosseini, S.H.; Farasat, M. Dynamic voltage restorer based on stacked multicell converter. In Proceedings of the 2009 IEEE Symposium on Industrial Electronics \& Applications, Kuala Lumpur, Malaysia, 4-6 October 2009; Volume 1, pp. 419-424. [CrossRef]

82. Wang, B.; Venkataramanan, G. Dynamic voltage restorer utilizing a matrix converter and flywheel energy storage. IEEE Trans. Ind. Appl. 2009, 45, 222-231. [CrossRef]

83. Pérez, J.; Cárdenas, V.; Moran, L.; Núñez, C. Single-phase ac-ac converter operating as a dynamic voltage restorer (DVR). In Proceedings of the IECON 2006-32nd Annual Conference on IEEE Industrial Electronics, Paris, France, 7-10 November 2006; pp. 1938-1943. [CrossRef]

84. Lozano, J.M.; Ramirez, J.M.; Correa, R.E. A novel dynamic voltage restorer based on matrix converters. In Proceedings of the 2010 Modern Electric Power Systems, Wroclaw, Poland, 20-22 September 2010; pp. 1-7.

85. Choi, N.S.; Han, B.M.; Nho, E.C.; Cha, H. Dynamic voltage restorer using PWM ac-ac converter. In Proceedings of the 2010 International Power Electronics Conference-ECCE ASIA-, Sapporo, Japan, 21-24 June 2010; pp. 2690-2695. [CrossRef]

86. Wang, B. A series compensator based on AC-AC power converters with virtual quadrature modulation. In Proceedings of the 2nd International Symposium on Power Electronics for Distributed Generation Systems, Hefei, China, 16-18 June 2010; pp. 438-443. [CrossRef]

87. Ramirez, J.M.; Garcia-Vite, P.; Lozano, J.M.; Mancilla-David, F. Dynamic voltage restorers based on AC-AC topologies. In Proceedings of the 2012 IEEE Power and Energy Society General Meeting, San Diego, CA, USA, 22-26 July 2012; pp. 1-7. [CrossRef]

88. Garcia-Vite, P.M.; Mancilla-David, F.; Ramirez, J.M. Per-sequence vector-switching matrix converter modules for voltage regulation. IEEE Trans. Ind. Electron. 2012, 60, 5411-5421. [CrossRef] 
89. Hietpas, S.M.; Naden, M. Automatic voltage regulator using an AC voltage-voltage converter. IEEE Trans. Ind. Appl. 2000, 36, 33-38. [CrossRef]

90. Prasai, A.; Divan, D.M. Zero-energy sag correctors-Optimizing dynamic voltage restorers for industrial applications. IEEE Trans. Ind. Appl. 2008, 44, 1777-1784. [CrossRef]

91. Subramanian, S.; Mishra, M.K. Interphase AC-AC topology for voltage sag supporter. IEEE Trans. Power Electron. 2009, 25, 514-518. [CrossRef]

92. Nguyen, M.K.; Jung, Y.G.; Lim, Y.C. Voltage swell/sag compensation with single-phase Z-source AC/AC converter. In Proceedings of the 2009 13th European Conference on Power Electronics and Applications, Barcelona, Spain, 8-10 September 2009; pp. 1-8.

93. Jothibasu, S.; Mishra, M.K. An improved direct AC-AC converter for voltage sag mitigation. IEEE Trans. Ind. Electron. 2014, 62, 21-29. [CrossRef]

94. Fitzer, C.; Barnes, M.; Green, P. Voltage sag detection technique for a dynamic voltage restorer. IEEE Trans. Ind. Appl. 2004, 40, 203-212. [CrossRef]

95. Teke, A.; Bayindir, K.; Tümay, M. Fast sag/swell detection method for fuzzy logic controlled dynamic voltage restorer. IET Gener. Transm. Distrib. 2010, 4, 1-12. [CrossRef]

96. Gencer, Ö.; Öztürk, S.; Erfidan, T. A new approach to voltage sag detection based on wavelet transform. Int. J. Electr. Power Energy Syst. 2010, 32, 133-140. [CrossRef]

97. Kumsuwan, Y.; Sillapawicharn, Y. An application of improved synchronous reference frame-based voltage sag detection in voltage sag compensation system. In Proceedings of the 2013 15th European Conference on Power Electronics and Applications (EPE), Lille, France, 2-6 September 2013; pp. 1-8. [CrossRef]

98. Bae, B.; Lee, J.; Jeong, J.; Han, B. Line-interactive single-phase dynamic voltage restorer with novel sag detection algorithm. IEEE Trans. Power Deliv. 2010, 25, 2702-2709. [CrossRef]

99. Meena, P.; Rao, K.U.; Ravishankar, D. A modified simple algorithm for detection of voltage sags and swells in practical loads. In Proceedings of the 2009 International Conference on Power Systems, Kharagpur, India, 27-29 December 2009; pp. 1-6. [CrossRef]

100. Sadigh, A.K.; Smedley, K.M. Fast voltage sag detection method for single-/three-phase application. In Proceedings of the 2013 Twenty-Eighth Annual IEEE Applied Power Electronics Conference and Exposition (APEC), Long Beach, CA, USA, 17-21 March 2013; pp. 881-888. [CrossRef]

101. Hua, O.Y.; Bu, L.P.; Yang, Z.L. Voltage sag detection based on dq transform and mathematical morphology filter. Procedia Eng. 2011, 23, 775-779. [CrossRef]

102. Nath, S.; Sinha, P.; Goswami, S.K. A wavelet based novel method for the detection of harmonic sources in power systems. Int. J. Electr. Power Energy Syst. 2012, 40, 54-61. [CrossRef]

103. Abdollahzadeh, H.; Jazaeri, M.; Tavighi, A. A new fast-converged estimation approach for Dynamic Voltage Restorer (DVR) to compensate voltage sags in waveform distortion conditions. Int. J. Electr. Power Energy Syst. 2014, 54, 598-609. [CrossRef]

104. Ai, Q.; Zhou, Y.; Xu, W. Adaline and its application in power quality disturbances detection and frequency tracking. Electr. Power Syst. Res. 2007, 77, 462-469. [CrossRef]

105. Elnady, A.; Salama, M.M. Mitigation of voltage disturbances using adaptive perceptron-based control algorithm. IEEE Trans. Power Deliv. 2005, 20, 309-318. [CrossRef]

106. Saleh, S.A.; Moloney, C.R.; Rahman, M.A. Implementation of a dynamic voltage restorer system based on discrete wavelet transforms. IEEE Trans. Power Deliv. 2008, 23, 2366-2375. [CrossRef]

107. Sadigh, A.K.; Smedley, K.M. Fast and precise voltage sag detection method for dynamic voltage restorer (DVR) application. Electr. Power Syst. Res. 2016, 130, 192-207. [CrossRef]

108. Nielsen, J.G.; Newman, M.; Nielsen, H.; Blaabjerg, F. Control and testing of a dynamic voltage restorer (DVR) at medium voltage level. IEEE Trans. Power Electron. 2004, 19, 806-813. [CrossRef]

109. Styvaktakis, E.; Gu, I.Y.H.; Bollen, M.H.J. Voltage dip detection and power system transients. In Proceedings of the 2001 Power Engineering Society Summer Meeting. Conference Proceedings (Cat. No. 01CH37262), Vancouver, BC, Canada, 15-19 July 2004; Volume 1, pp. 683-688. [CrossRef]

110. Parsons, A.C.; Grady, W.M.; Powers, E.J. A wavelet-based procedure for automatically determining the beginning and end of transmission system voltage sags. In Proceedings of the IEEE Power Engineering Society. 1999 Winter Meeting (Cat. No. 99CH36233), New York, NY, USA, 31 January-4 February 1999; Volume 2, pp. 1310-1315. [CrossRef] 
111. Deckmann, S.M.; Ferrira, A.A. About voltage sags and swells analysis. In Proceedings of the 10th International Conference on Harmonics and Quality of Power. Proceedings (Cat. No. 02EX630), Rio de Janeiro, Brazil, 6-9 October 2002; Volume 1, pp. 144-148. [CrossRef]

112. Haichun, L.; Lizhi, X.; Shaojun, X. A new detection method of voltage sag based on period phase concept. In Proceedings of the 2009 4th IEEE Conference on Industrial Electronics and Applications, Xi'an, China, 25-27 May 2009; pp. 3333-3337. [CrossRef]

113. Li, B.H.; Choi, S.S.; Vilathgamuwa, D.M. Transformerless dynamic voltage restorer. IEE Proc.-Gener. Transm. Distrib. 2002, 149, 263-273. [CrossRef]

114. Li, P.; Xie, L.; Han, J.; Pang, S.; Li, P. New decentralized control scheme for a dynamic voltage restorer based on the elliptical trajectory compensation. IEEE Trans. Ind. Electron. 2017, 64, 6484-6495. [CrossRef]

115. Messiha, M.A.; Baraket, C.F.; Massoud, A.M.; Iqbal, A.; Soliman, R. Voltage sag mitigation employing dynamic voltage restorer with minimum energy requirements: Analysis and implementation. In Proceedings of the 8th IET International Conference on Power Electronics, Machines and Drives (PEMD 2016), Glasgow, UK, 19-21 April 2016; pp. 1-6. [CrossRef]

116. Remya, V.K.; Parthiban, P.; Ansal, V.; Nandakumar, A. Single-phase DVR with semi-Z-source inverter for power distribution network. Arab. J. Sci. Eng. 2018, 43, 3135-3149. [CrossRef]

117. Chu, H.Y.; Jou, H.L.; Huang, C.L. Transient response of a peak voltage detector for sinusoidal signals. IEEE Trans. Ind. Electron. 1992, 39, 74-79. [CrossRef]

118. Tunaboylu, N.S.; Collins, E.R.; Chaney, P.R. Voltage disturbance evaluation using the missing voltage technique. In Proceedings of the 8th International Conference on Harmonics and Quality of Power. Proceedings (Cat. No. 98EX227), Athens, Greece, 14-16 October 1998; Volume 1, pp. 577-582. [CrossRef]

119. Ding, K.; Cheng, K.W.E.; Xue, X.D.; Divakar, B.P.; Xu, C.D.; Che, Y.B.; Wang, D.H.; Dong, P. A novel detection method for voltage sags. In Proceedings of the 2006 2nd International Conference on Power Electronics Systems and Applications, Hong Kong, China, 12-14 November 2006; pp. 250-255. [CrossRef]

120. Sundarabalan, C.K.; Selvi, K. Compensation of voltage disturbances using PEMFC supported dynamic voltage restorer. Int. J. Electr. Power Energy Syst. 2015, 71, 77-92. [CrossRef]

121. Bollen, M.H.J.; Gu, I.Y.H. Signal Processing of Power Quality Disturbances; Wiley: Hoboken, NJ, USA, 2006.

122. Vilathgamuwa, M.; Perera, A.A.D.R.; Choi, S.S.; Tseng, K.J. Control of energy optimized dynamic voltage restorer. In Proceedings of the IECON'99, Conference Proceedings, 25th Annual Conference of the IEEE Industrial Electronics Society (Cat. No. 99CH37029), San Jose, CA, USA, 29 November-3 December 1999; Volume 2, pp. 873-878. [CrossRef]

123. Li, P.; Xie, L.; Han, J.; Pang, S.; Li, P. A new voltage compensation philosophy for dynamic voltage restorer to mitigate voltage sags using three-phase voltage ellipse parameters. IEEE Trans. Power Electron. 2017, 33, 1154-1166. [CrossRef]

124. Lobos, T. Nonrecursive methods for real-time determination of basic waveforms of voltages and currents. IEEE Proc. C (Gener. Transm. Distrib.) 1989, 136, 347-351. [CrossRef]

125. Huang, J.; Negnevitsky, M.; Nguyen, D.T. A neural-fuzzy classifier for recognition of power quality disturbances. IEEE Trans. Power Deliv. 2002, 17, 609-616. [CrossRef]

126. Chung, I.Y.; Won, D.J.; Park, S.Y.; Moon, S.I.; Park, J.K. The DC link energy control method in dynamic voltage restorer system. Int. J. Electr. Power Energy Syst. 2003, 25, 525-531. [CrossRef]

127. Won, D.J.; Ahn, S.J.; Chung, I.Y.; Kim, J.M.; Moon, S.I. A new definition of voltage sag duration considering the voltage tolerance curve. In Proceedings of the 2003 IEEE Bologna Power Tech Conference Proceedings, Bologna, Italy, 23-26 June 2003; Volume 3, p. 5. [CrossRef]

128. Nielsen, J.G.; Blaabjerg, F.; Mohan, N. Control strategies for dynamic voltage restorer compensating voltage sags with phase jump. In Proceedings of the APEC 2001, Sixteenth Annual IEEE Applied Power Electronics Conference and Exposition (Cat. No. 01CH37181), Anaheim, CA, USA, 4-8 March 2001; Volume 2, pp. 1267-1273. [CrossRef]

129. Sadigh, A.K.; Smedley, K.M. Review of voltage compensation methods in dynamic voltage restorer (DVR). In Proceedings of the 2012 IEEE Power and Energy Society General Meeting, San Diego, CA, USA, 22-26 July 2012; pp. 1-8. [CrossRef]

130. Hosseini, S.H.; Banaei, M.R. A new minimal energy control of the DC link energy in four-wire dynamic voltage restorer. In Proceedings of the 30th Annual Conference of IEEE Industrial Electronics Society, 2004, IECON, Busan, South Korea, 2-6 November 2004; Volume 3, pp. 3048-3053. [CrossRef] 
131. Banaei, M.R.; Nahavandi, A.; Hosseini, S.H. Investigation of multi-functional DVR to improve power quality characteristic. In Proceedings of the 2009 6th International Conference on Electrical Engineering/Electronics, Computer, Telecommunications and Information Technology, Pattaya, Chonburi, Thailand, 6-9 May 2009; Volume 1, pp. 144-149. [CrossRef]

132. Sadigh, A.K.; Hosseini, S.H.; Barakati, S.M.; Gharehpetian, G. Stacked multicell converter based DVR with energy minimized compensation strategy. In Proceedings of the 41st North American Power Symposium, Starkville, MS, USA, 4-6 October 2009; pp. 1-6. [CrossRef]

133. Marei, M.I.; El-Saadany, E.F.; Salama, M.M. A new approach to control DVR based on symmetrical components estimation. IEEE Trans. Power Deliv. 2007, 22, 2017-2024. [CrossRef]

134. Fernandes, D.A.; Naidu, S.R.; CouraJr, C.A.E. Instantaneous sequence-component resolution of 3-phase variables and its application to dynamic voltage restoration. IEEE Trans. Instrum. Meas. 2009, 58, 2580-2587. [CrossRef]

135. Lee, S.J.; Kim, H.; Sul, S.K.; Blaabjerg, F. A novel control algorithm for static series compensators by use of PQR instantaneous power theory. IEEE Trans. Power Electron. 2004, 19, 814-827. [CrossRef]

136. Chen, G.; Zhu, M.; Cai, X. Medium-voltage level dynamic voltage restorer compensation strategy by positive and negative sequence extractions in multiple reference frames. IET Power Electron. 2014, 7, 1747-1758. [CrossRef]

137. Ebrahimzadeh, E.; Farhangi, S.; Iman-Eini, H.; Ajaei, F.B.; Iravani, R. Improved phasor estimation method for dynamic voltage restorer applications. IEEE Trans. Power Deliv. 2014, 30, 1467-1477. [CrossRef]

138. Amalorpavaraj, R.A.J.; Kaliannan, P.; Padmanaban, S.; Subramaniam, U.; Ramachandaramurthy, V.K. Improved fault ride through capability in DFIG based wind turbines using dynamic voltage restorer with combined feed-forward and feed-back control. IEEE Access 2017, 5, 20494-20503. [CrossRef]

139. Shen, K.; Wang, J.; Gao, Z.; Cai, X.; Ji, Y. Dynamic voltage restorer based on proportional-resonant control. In Proceedings of the 2010 Asia-Pacific Power and Energy Engineering Conference, Chengdu, China, 28-31 March 2010; pp. 1-4. [CrossRef]

140. Li, Y.W.; Blaabjerg, F.; Vilathgamuwa, D.M.; Loh, P.C. Design and comparison of high performance stationary-frame controllers for DVR implementation. IEEE Trans. Power Electron. 2007, 22, 602-612. [CrossRef]

141. Li, Y.W.; Vilathgamuwa, D.M.; Blaabjerg, F.; Loh, P.C. A robust control scheme for medium-voltage-level DVR implementation. IEEE Trans. Ind. Electron. 2007, 54, 2249-2261. [CrossRef]

142. Roncero-Sánchez, P.; Acha, E.; Ortega-Calderon, J.E.; Feliu, V.; García-Cerrada, A. A versatile control scheme for a dynamic voltage restorer for power-quality improvement. Ieee Trans. Power Deliv. 2008, 24, 277-284. [CrossRef]

143. Roldán-Pérez, J.; García-Cerrada, A.; Zamora-Macho, J.L.; Roncero-Sánchez, P.; Acha, E. Troubleshooting a digital repetitive controller for a versatile dynamic voltage restorer. Int. J. Electr. Power Energy Syst. 2014, 57, 105-115. [CrossRef]

144. Kumar, C.; Mishra, M.K. Predictive voltage control of transformerless dynamic voltage restorer. IEEE Trans. Ind. Electron. 2014, 62, 2693-2697. [CrossRef]

145. Zhou, H.; Wei, T.Z.; Zhao, Y.L.; Qi, Z.P. Study on dynamic matrix predictive control of single-phase DVR. In Proceedings of the 2008 Third International Conference on Electric Utility Deregulation and Restructuring and Power Technologies, Nanjing, China, 6-9 April 2008; pp. 2136-2140. [CrossRef]

146. Kim, H.; Sul, S.K. Compensation voltage control in dynamic voltage restorers by use of feed forward and state feedback scheme. IEEE Trans. Power Electron. 2005, 20, 1169-1177. [CrossRef]

147. Joos, G.; Chen, S.; Lopes, L. Closed-loop state variable control of dynamic voltage restorers with fast compensation characteristics. In Proceedings of the Conference Record of the 2004 IEEE Industry Applications Conference, 2004, 39th IAS Annual Meeting, Seattle, WA, USA, 3-7 October 2004; Volume 4, pp. 2252-2258. [CrossRef]

148. Sarhangzadeh, M.; Hosseini, S.H.; Sharifian, M.B.B.; Gharehpetian, G.B.; Sarhangzadeh, O. Dynamic analysis of DVR implementation based on nonlinear control by IOFL. In Proceedings of the 2011 24th Canadian Conference on Electrical and Computer Engineering (CCECE), Niagara Falls, ON, Canada, 8-11 May 2011; pp. 000264-000269. [CrossRef]

149. Biricik, S.; Komurcugil, H.; Tuyen, N.D.; Basu, M. Protection of sensitive loads using sliding mode controlled three-phase DVR with adaptive notch filter. IEEE Trans. Ind. Electron. 2018, 66, 5465-5475. [CrossRef] 
150. Piatek, K. Sliding mode control of DVR with minimized energy injection. In Proceedings of the 2005 European Conference on Power Electronics and Applications, Dresden, Germany, 11-14 September 2005; p. 8. [CrossRef]

151. Ruilin, P.; Yuegen, Z. Sliding mode control strategy of dynamic voltage restorer. In Proceedings of the 2005 International Conference on Industrial Electronics and Control Applications, Quito, Ecuador, 29 November-2 December 2005; p. 3. [CrossRef]

152. Biricik, S.; Komurcugil, H. Optimized sliding mode control to maximize existence region for single-phase dynamic voltage restorers. IEEE Trans. Ind. Inform. 2016, 12, 1486-1497. [CrossRef]

153. Al-Ammar, E.A.; Ul-Haq, A.; Iqbal, A.; Jalal, M.; Anjum, A. SRF based versatile control technique for DVR to mitigate voltage sag problem in distribution system. Ain Shams Eng. J. 2020, 11, 99-108. [CrossRef]

154. Sundarabalan, C.K.; Selvi, K. Real coded GA optimized fuzzy logic controlled PEMFC based Dynamic Voltage Restorer for reparation of voltage disturbances in distribution system. Int. J. Hydrogen Energy 2017, 42, 603-613. [CrossRef]

155. Moreno, F.B.; Palacios, J.E.; Posada, J.; Lopez, J.A. Implementation and evaluation of a new DVR topology with AC link for series compensation. Electr. Power Syst. Res. 2020, 181, 106184. [CrossRef]

156. Mosaad, M.I.; El-Raouf, M.O.A.; Al-Ahmar, M.A.; Bendary, F.M. Optimal PI controller of DVR to enhance the performance of hybrid power system feeding a remote area in Egypt. Sustain. Cities Soc. 2019, 47, 101469. [CrossRef]

157. Khalghani, M.R.; Shamsi-Nejad, M.A.; Khooban, M.H. Dynamic voltage restorer control using bi-objective optimisation to improve power quality's indices. IET Sci. Meas. Technol. 2014, 8, 203-213. [CrossRef]

158. Jing, W.; Aiqin, X.; Yueyue, S. A survey on control strategies of dynamic voltage restorer. In Proceedings of the 2008 13th International Conference on Harmonics and Quality of Power, Wollongong, NSW, Australia, 28 September-1 October 2008; pp. 1-5. [CrossRef]

159. Jurado, F. Neural network control for dynamic voltage restorer. IEEE Trans. Ind. Electron. 2004, 51, 727-729. [CrossRef]

160. Torres, A.P.; Roncero-Sánchez, P.; Vázquez, J.; López-Alcolea, F.J.; Molina-Martínez, E.J. A discrete-time control method for fast transient voltage-sag compensation in DVR. IEEE Access 2019, 7, 170564-170577. [CrossRef]

161. Zhang, S.; Zhao, Z.; Zhao, J.; Jin, L.; Wang, H.; Sun, H.; Liu, K.; Yang, B. Control strategy for dynamic voltage restorer under distorted and unbalanced voltage conditions. In Proceedings of the 2019 IEEE International Conference on Industrial Technology (ICIT), Melbourne, Australia, 13-15 February 2019; pp. 411-416. [CrossRef]

162. Zhan, C.; Arulampalam, A.; Jenkins, N. Four-wire dynamic voltage restorer based on a three-dimensional voltage space vector PWM algorithm. IEEE Trans. Power Electron. 2003, 18, 1093-1102. [CrossRef]

163. Ding, H.; Shuangyan, S.; Xianzhong, D.; Jun, G. A novel dynamic voltage restorer and its unbalanced control strategy based on space vector PWM. Int. J. Electr. Power Energy Syst. 2002, 24, 693-699. [CrossRef]

164. Newman, M.J.; Holmes, D.G.; Nielsen, J.G.; Blaabjerg, F. A dynamic voltage restorer (DVR) with selective harmonic compensation at medium voltage level. IEEE Trans. Ind. Appl. 2005, 41, 1744-1753. [CrossRef]

165. Zhao, Y. Design and implementation of inverter in dynamic voltage restorer based on selective harmonic elimination PWM. In Proceedings of the 2008 Third International Conference on Electric Utility Deregulation and Restructuring and Power Technologies, Nanjing, China, 6-9 April 2008; pp. 2239-2244. [CrossRef]

166. Iyer, R.K.; Ramasamy, A.K.; Ramachandaramuthy, V.K.; Murkerjee, R.N. Fundamental frequency model of a dynamic voltage restorer. In Proceedings of the 2005 International Conference on Power Electronics and Drives Systems, Kuala Lumpur, Malaysia, 11-14 September 2005; Volume 1, pp. 548-552. [CrossRef]

167. Zheng, Z.X.; Xiao, X.Y.; Chen, X.Y.; Huang, C.J.; Zhao, L.H.; Li, C.S. Performance evaluation of a MW-class SMES-BES DVR system for mitigation of voltage quality disturbances. IEEE Trans. Ind. Appl. 2018, 54, 3090-3099. [CrossRef]

168. Jowder, F.A. Modeling and simulation of dynamic voltage restorer (DVR) based on hysteresis voltage control. In Proceedings of the IECON 2007-33rd Annual Conference of the IEEE Industrial Electronics Society, Taipei, Taiwan, 5-8 November 2007; pp. 1726-1731. [CrossRef]

169. Hosseini, S.H.; Sabahi, M. Three-phase DVR using a single-phase structure with combined hysteresis/dead-band control. In Proceedings of the 2006 CES/IEEE 5th International Power Electronics and Motion Control Conference, Shanghai, China, 14-16 August 2006; Volume 3, pp. 1-5. [CrossRef] 
170. De Almeida Carlos, G.A.; dos Santos, E.C.; Jacobina, C.B.; Mello, J.P.R.A. Dynamic voltage restorer based on three-phase inverters cascaded through an open-end winding transformer. IEEE Trans. Power Electron. 2015, 31, 188-199. [CrossRef]

171. Shuai, Z.; Yao, P.; Shen, Z.J.; Tu, C.; Jiang, F.; Cheng, Y. Design considerations of a fault current limiting dynamic voltage restorer (FCL-DVR). IEEE Trans. Smart Grid 2014, 6, 14-25. [CrossRef]

172. Li, Y.W.; Vilathgamuwa, D.M.; Loh, P.C.; Blaabjerg, F. A dual-functional medium voltage level DVR to limit downstream fault currents. IEEE Trans. Power Electron. 2007, 22, 1330-1340. [CrossRef]

173. Ajaei, F.B.; Afsharnia, S.; Kahrobaeian, A.; Farhangi, S. A fast and effective control scheme for the dynamic voltage restorer. IEEE Trans. Power Deliv. 2011, 26, 2398-2406. [CrossRef]

174. Ajaei, F.B.; Farhangi, S.; Iravani, R. Fault current interruption by the dynamic voltage restorer. IEEE Trans. Power Deliv. 2013, 28, 903-910. [CrossRef]

175. Vilathgamuwa, D.; Wijekoon, H.M.; Choi, S.S. A novel technique to compensate voltage sags in multiline distribution system-The interline dynamic voltage restorer. IEEE Trans. Ind. Electron. 2006, 53, 1603-1611. [CrossRef]

176. Usha, R.P.; Sudha, R.; Reddy, S.R. Voltage sag/swell compensation in an interline dynamic voltage restorer. In Proceedings of the 2011 International Conference on Emerging Trends in Electrical and Computer Technology, Nagercoil, India, 23-24 March 2011; pp. 309-314. [CrossRef]

177. Moradlou, M.; Bigdeli, M.; Siano, P.; Jamadi, M. Minimization of interline dynamic voltage restorers rated apparent power in an industrial area consisting of two independent feeders considering daily load variations. Electr. Power Syst. Res. 2017, 149, 65-75. [CrossRef]

178. Ho, C.N.M.; Chung, H.S.H. Implementation and performance evaluation of a fast dynamic control scheme for capacitor-supported interline DVR. IEEE Trans. Power Electron. 2010, 25, 1975-1988. [CrossRef]

179. Zhang, L.; Loh, P.C.; Gao, F.; Blaabjerg, F. Reduced semiconductor three-level interline dynamic voltage restorer. In Proceedings of the 8th International Conference on Power Electronics-ECCE Asia, Jeju, South Korea, 29 May-2 June 2011; pp. 1843-1847. [CrossRef]

180. Vilathgamuwa, D.M.; Wijekoon, H.M.; Choi, S.S. Interline dynamic voltage restorer: A novel and economical approach for multiline power quality compensation. IEEE Trans. Ind. Appl. 2004, 40, 1678-1685. [CrossRef]

181. Shahabadini, M.; Iman-Eini, H. Improving the performance of a cascaded H-bridge-based interline dynamic voltage restorer. IEEE Trans. Power Deliv. 2015, 31, 1160-1167. [CrossRef]

182. Sasitharan, S.; Mishra, M.K.; Kumar, B.K.; Jayashankar, V. Rating and design issues of DVR injection transformer. In Proceedings of the 2008 Twenty-Third Annual IEEE Applied Power Electronics Conference and Exposition, Austin, TX, USA, 24-26 February 2008; pp. 449-455. [CrossRef]

183. Sng, E.K.K.; Choi, S.S.; Vilathgamuwa, D.M. Analysis of series compensation and DC-link voltage controls of a transformerless self-charging dynamic voltage restorer. IEEE Trans. Power Deliv. 2004, 19, 1511-1518. [CrossRef]

184. Moghassemi, A.; Ebrahimi, S. Application of Renewable Energy Systems in MATLAB/Simulink Software: PV Solar and Wind Turbine; Roham Andisheh Press: Tehran, Iran, 2019.

185. Gandoman, F.H.; Ahmadi, A.; Sharaf, A.M.; Siano, P.; Pou, J.; Hredzak, B.; Agelidis, V.G. Review of FACTS technologies and applications for power quality in smart grids with renewable energy systems. Renew. Sustain. Energy Rev. 2018, 82, 502-514. [CrossRef]

186. Ramasamy, M.; Thangavel, S. Photovoltaic based dynamic voltage restorer with outage handling capability using PI controller. Energy Procedia 2011, 12, 560-569. [CrossRef]

187. Divyalakshmi, D.; Subramaniam, N.P. Photovoltaic based DVR with power quality detection using wavelet transform. Energy Procedia 2017, 117, 458-465. [CrossRef]

188. Ramasamy, M.; Thangavel, S. Photovoltaic based dynamic voltage restorer with power saver capability using PI controller. Int. J. Electr. Power Energy Syst. 2012, 36, 51-59. [CrossRef]

189. Sagha, H.; Mokhtari, G.; Arefi, A.; Nourbakhsh, G.; Ledwich, G.; Ghosh, A. A new approach to improve PV power injection in LV electrical systems using DVR. IEEE Syst. J. 2017, 12, 3324-3333. [CrossRef]

190. Liu, X.; Li, P. The effect of DVR on distribution system with distributed generation. In Proceedings of the 2007 International Conference on Electrical Machines and Systems (ICEMS), Seoul, South Korea, 8-11 October 2007; pp. 277-281. 
191. Aghazadeh, A.; Noroozian, R.; Jalilvand, A.; Haeri, H. Combined operation of dynamic voltage restorer with distributed generation in custom power park. In Proceedings of the 2011 10th International Conference on Environment and Electrical Engineering, Rome, Italy, 8-11 May 2011; pp. 1-4. [CrossRef]

192. Olamaei, J.; Ebrahimi, S.; Moghassemi, A. Compensation of voltage sag caused by partial shading in grid-connected PV system through the three-level SVM inverter. Sustain. Energy Technol. Assess. 2016, 18, 107-118. [CrossRef]

193. Wessels, C.; Gebhardt, F.; Fuchs, F.W. Fault ride-through of a DFIG wind turbine using a dynamic voltage restorer during symmetrical and asymmetrical grid faults. IEEE Trans. Power Electron. 2010, 26, 807-815. [CrossRef]

194. Alaraifi, S.; Moawwad, A.; El Moursi, M.S.; Khadkikar, V. Voltage booster schemes for fault ride-through enhancement of variable speed wind turbines. IEEE Trans. Sustain. Energy 2013, 4, 1071-1081. [CrossRef]

195. Ibrahim, A.O.; Nguyen, T.H.; Lee, D.C.; Kim, S.C. A fault ride-through technique of DFIG wind turbine systems using dynamic voltage restorers. IEEE Trans. Energy Convers. 2011, 26, 871-882. [CrossRef]

196. Ramirez, D.; Martinez, S.; Platero, C.A.; Blazquez, F.; De Castro, R.M. Low-voltage ride-through capability for wind generators based on dynamic voltage restorers. IEEE Trans. Energy Convers. 2010, 26, 195-203. [CrossRef]

197. Gkavanoudis, S.I.; Demoulias, C.S. Fault ride-through capability of a DFIG in isolated grids employing DVR and supercapacitor energy storage. Int. J. Electr. Power Energy Syst. 2015, 68, 356-363. [CrossRef]

198. Sebastian, P.; Nair, U. Improved low voltage ride through capability of a fixed speed wind generator using dynamic voltage restorer. Procedia Technol. 2016, 25, 767-774. [CrossRef]

199. Jirdehi, M.A.; Tabar, V.S.; Hemmati, R.; Siano, P. Multi objective stochastic microgrid scheduling incorporating dynamic voltage restorer. Int. J. Electr. Power Energy Syst. 2017, 93, 316-327. [CrossRef]

200. Moghassemi, A.; Ebrahimi, S.; Olamaei, J. Maximum power point tracking methods used in photovoltaic systems: A review. Signal Process. Renew. Energy 2020. Available online: http://spre.azad.ac.ir/article_673100. html (accessed on 27 May 2020).

201. Moghassemi, A.; Ebrahimi, S.; Olamaei, J. MPPT and current mode control methods for PV modules: A review and a new multi-loop integrated method. Signal Process. Renew. Energy 2020, 4, 1-22. Available online: http://spre.azad.ac.ir/article_673589.html (accessed on 14 June 2020).

202. Chawda, G.S.; Shaik, A.G.; Mahela, O.P.; Padmanaban, S.; Holm-Nielse, J.B. Comprehensive review of distributed FACTS control algorithms for power quality enhancement in utility grid with renewable energy penetration. IEEE Access 2020, 8, 107614-107634. [CrossRef] 